\title{
PENGARUH PROMOSI, PERSEPSI KEMUDAHAN DAN PERSEPSI MANFAAT \\ TERHADAP MINAT PENGGUNAAN E-WALLET DENGAN KEPERCAYAAN \\ SEBAGAI VARIABEL MEDIASI PADA PENGGUNA E-WALLET \\ DI KOTA BANJARMASIN
}

\author{
Lalu Agustino, Ujianto, Imawati Yousida \\ Sekolah Tinggi Ilmu Ekonomi Pancasetia Banjarmasin \\ Jl. Ahmad Yani Km. 5.5 Banjarmasin \\ laluagustino1981@gmail.com
}

\begin{abstract}
This study aims to explain the effect of promotion, perceived convenience, and perceived benefits on user interest with trust as a mediating variable. This research was conducted in Banjarmasin and the population in this study were e-wallet users. The sampling technique used in this research is purposive sampling method with 100 respondents. Methods of data collection using a questionnaire through a definite google form. The data analysis technique used is SEM (Structural Equation Modeling) to determine the relationship between variables with the AMOS 24 application and the Sobel test to determine the role of mediation.

The results of this study indicate that promotion, perceived ease of use and perceived usefulness have a positive and significant effect on trust and interest in using, trust has a positive and significant effect on interest in using e-wallet. Trust is able to mediate positively and significantly the effect of promotion, perceived ease of use and perceived usefulness on interest in using e-wallet.
\end{abstract}

Keywords: promotion, perceived ease of use, perceived usefulness, interest in using

\begin{abstract}
Abstrak: Penelitian ini bertujuan untuk menjelaskan pengaruh pengaruh promosi, persepsi kemudahan, dan persepsi manfaat terhadap minat penggunaan dengan kepercayaan sebagai variable mediasi. Penelitian ini dilakukan di Banjarmasin dan populasi pada penelitian ini adalah masyarakat pengguna e-wallet. Teknik pengambilan sampel yang digunakan pada penelitian ini adalah metode purposive sampling dengan jumlah responden 100 orang. Metode pengumpulan data menggunakan kuesioner melalui google form. Teknik analisis data yang digunakan adalah SEM (Structural Equation Modeling) untuk mengetahui hubungan antar variabel dengan aplikasi AMOS 24 dan Uji Sobel untuk mengetahui peran mediasi.

Hasil penelitian ini menunjukkan bahwa promosi, persepsi kemudahan dan persepsi manfaat berpengaruh positif dan signifikan terhadap kepercayaan dan minat penggunaan, kepercayaan berpengaruh positif dan signifikan terhadap minat penggunaan e-wallet. Kepercayaan mampu memediasi secara positif dan signifikan pengaruh promosi, persepsi kemudahan dan persepsi manfaat terhadap minat pengunaan e-wallet.
\end{abstract}

Kata kunci: promosi, persepsi kemudahan, persepsi manfaat, minat penggunaan 


\section{Latar Belakang}

Penyebaran Covid-19 sangat cepat hingga akhirnya menjadi pandemi global. Hal ini sangat berpengaruh kepada kestabilan perekonomian dunia. Pandemi Covid-19 ini telah merubah tatanan hidup manusia. Himbauan untuk menjaga jarak dan anjuran untuk "stay at home" dalam rangka memutus rantai penyebaran Covid-19 mengakibatkan ruang gerak manusia menjadi terbatas. Hal ini mengakibatkan adanya peningkatan transaksi belanja secara online dan penggunaan $e$-wallet dikalangan masyarakat (Nadhilla, 2020:4).

Pembatasan kegiatan di luar ini memengaruhi aktivitas individu dalam melakukan pembelian. Kebiasaan berbelanja dimasyarakat mengalami banyak perubahan semenjak pandemik virus corona ini masuk ke Indonesia, karena dengan adanya pembatasan untuk melakukan kegiatan di luar rumah, masyakarat memilih untuk berbelanja melalui online. Penggunaan $e$-wallet memang sangat mempemudah masyarakat dalam melakukan transaksi, terlebih untuk membatasi penggunaan uang tunai atau kertas. Meskipun belum ada pemberitahuan resmi, termasuk dari Badan Kesehatan Dunia (WHO) bahwa uang tunai bisa menjadi vektor penularan covid-19. Namun, psikologis publik yang menganggap bahwa uang tunai tidak bersih dapat menjadi jembatan bagi penularan virus membuat orang berasumsi untuk beralih ke pembayaran digital.

Transaksi digital kian meroket tajam di era pandemic Covid-19. Hal itu bisa dilihat berdasarkan catatan dari Bank Indonesia (BI) bahwa transaksi digital mengalami peningkatan sebesar 37,8 persen (year on year) yaitu mencakup digital banking dan transfer. Penggunaan dompet digital (e-wallet) juga mengalami peningkatan sebesar
24,42 persen (year on year), sementara penggunaan kartu debit mengalami penurunan menjadi 18,9 persen (year on year). Kondisi pandemic Covid-19 ini telah mempercepat transformasi digital di Indonesia, diluar prediksi yang sudah dirancang. Hal itu karena masyarakat menghindari kontak fisik, dan beralih melakukan berbagai kegiatannya melalui platform digital.

Di era pandemic Covid-19 ini, penggunaan uang digital khususnya EWallet semain meningkat. Berdasarkan hasil riset Neurosensum, sebuah perusahaan riset yang berbasis tekhnologi neuroscience artificial intelegence mengungkapkan bahwa pengguna dompet digital atau e-wallet menglamai peningkatan yang drastis sebesar $44 \%$ dalam setahun pasca terjadinya pandemi Covid-19. Lonjakan tersebut dipicu karena meningkatnya kecendrungan belanja daring di $e$ commerce, dan hal ini adalah tren yang sangat menarik dan kemungkinan penggunaan dompet digital atau $e$-wallet di Indonesia akan semakin meningkat.

Beralihnya masyarakat dalam penggunaan uang tunai ke transaksi digital akhir-akhir ini menjadi menarik untuk dikaji, agar dapat diketahui sejauh mana dampak covid-19 terhadap perilaku konsumen dalam penggunaan layanan mobile payment, salah satunya adalah e-wallet. Menurut RedSeer (dalam Kusumastuti, 2020:230) penggunaan sejumlah layanan digital di Indonesia meningkat selama pandemi covid-19, salah satunya e-commerce. Sebanyak $69 \%$ konsumen beralih menggunakan layanan ini untuk membeli kebutuhan sehari-hari. Penggunaan dompet digital juga mengalami peningkatan $65 \%$, sebagai alat transaksi pembelian tersebut. Selanjutnya layanan digital di bidang kesehatan dan pendidikan yang mengalami peningkatan masing-masing sebesar $41 \%$ dan $38 \%$. 
Berdasarkan hasil survey dari Snapcart data jumlah pengguna $e$-wallet pada maret 2021, e-wallet yang paling banyak digunakan adalah Shoopepay (76\%), selanjutnya disusul oleh Gopay (57\%), Ovo (54\%), Dana (49\%) dan LinkAja (21\%) seperti yang ter pada grafik berikut ini:

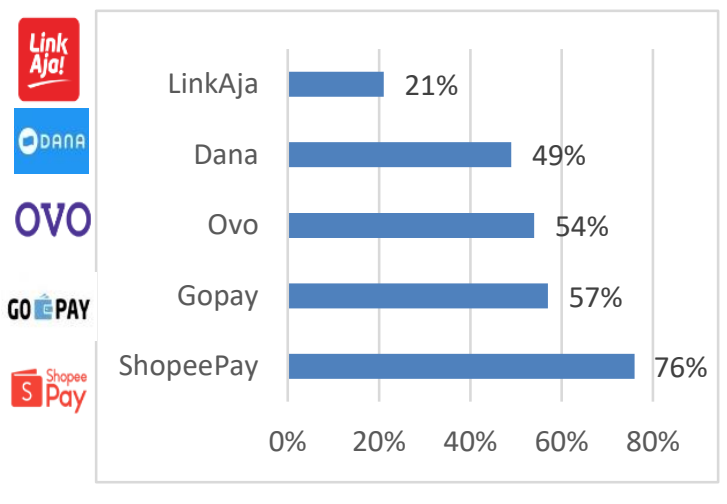

Sumber : Snapchart (2021)

Kemunculan berbagai macam $e$ wallet dengan segala macam kelebihan dan kekurangannya

pada akhirnya akan membuat masyarakat harus selektif membuat keputusan penggunaan $e$-wallet yang tepat untuk bertransaksi dalam kehidupan sehari-hari (Widiyanti,2020:56). Indonesia penyedia layanan $e$-wallet yang besar termasuk sangat beragam seperti, go-pay, ovo, linkaja, dana, jenius, sakuku, go mobile dan yang lainnya. dengan adanya banyaknya layanan e-wallet setiap penyedia layanan harus bisa lebih berinovasi dan harus bisa menjaga kualitas kinerjanya di sisi teknologi, kemudahan yang diperoleh, pemasaran yang diterapkan, keamanan, manfaat yang diberikan, dan tentang tingkat pelayanan.

Perkembangan $e$-wallet di tengah masyarakat tidak lepas dari berbagai promosi. Promosi sebagai salah satu alat pemasaran yang dapat menarik minat konsumen. Sebagai salah satu bagian dari pemasaran, promosi merupakan suatu unsur yang penting serta dapat mempengaruhi minat penggunaan $e$ wallet. Menurut Gitosudarmo (2014:155) promosi merupakan kegiatan yang ditunjukkan untuk mempengaruhi konsumen agar mereka dapat menjadi kenal akan produk yang ditawarkan oleh perusahaan kepada mereka dan kemudian mereka menjadi senang lalu membeli produk tersebut.

Promosi yang dapat dilakukan diantaranya adalah cashback dan diskon serta penggunaan poin yang dapat digunakan untuk bertransaksi kembali, sehingga dapat menghemat pengeluaran. Hasil penelitian yang telah dilakukan oleh Dirwan dan Latief (2020:7) menunjukkan bahwa promosi berpengaruh positif dan signifikan terhadap minat penggunaan dompet digital.

Persepsi kemudahan atau perceived ease of use merupakan salah satu faktor penentu dasar penerimaan sebuah teknologi. Kemudahan penggunaan merupakan kepercayaan seseorang dimana dalam penggunaan suatu teknologi dapat dengan mudah digunakan dan dipahami. Kemudahan penggunaan $e$-wallet merupakan salah satu faktor yang harus diperhatikan perusahaan, karena dengan kemudahan penggunaan memungkinkan pengguna akan terus menerus menggunakan $e$ wallet. Karena kemudahan penggunaan merupakan yang diinginkan pengguna dalam penggunaan $e$-wallet.

Berdasarkan hasil penelitian yang telah dilakukan Zulqurnain (2017:92), hasil penelitiannya menunjukkan bahwa persepsi kemudahan mempengaruhi minat menggunakan $e$-money secara positif dan signifikan. Sama halnya dengan Inayah (2020:118), hasil penelitiannya menunjukkan bahwa persepsi kemudahan memiliki pengaruh yang signifikan terhadap minat penggunaan uang elektronik. 
Selain kemudahan penggunaan, manfaat (perceived usefulness) yang diberikan $e$-wallet sangat berperan penting terhadap minat penggunaan $e$ wallet. Apabila penggunaan $e$-wallet merasakan manfaat secara terus menerus ketika menggunakan e-wallet, maka pengguna akan menggunakan $e$-wallet secara continue. Menurut Purba, dkk (2020:154) persepsi manfaat adalah tingkatan kepercayaan pengguna bahwa teknologi atau sistem tertentu dapat meningkatkan performa mereka dalam bekerja. Ketika seseorang pengguna telah merasakan manfaat yang sesuai dengan janji yang ditawarkan oleh sebuah aplikasi khusunya aplikasi $e$ wallet maka akan muncul kepuasan dari pengguna tersebut.

Pada penelitian Hong Zhu et.al., (2017:369) dijelaskan bahwa faktor yang menentukan seseorang dalam intention to continue use, adanya subjective norms, dan competitor marketing efforts. Dalam penelitian ini juga dijelaskan bahwa kepercayaan merupakan mediator yang sangat berpengaruh terhadap intention to continue use. Selanjutnya Ponte et.al., (2015:286) dalam penelitiannya menyimpulkan bahwa kepercayaan berpengaruh positif terhadap niat pembelian konsumen.

Semakin tinggi kepercayaan konsumen, keputusan untuk melakukan suatu pembelian terhadap suatu produk akan meningkat (Murwatiningsih dan Apriliani, 2013:180). Kepercayaan ini merupakan tanggungjawab penyelenggara $e$-wallet, yakni dengan memberikan jaminan keamanan dan kerahasiaan transaksi, sehingga dapat membuat penggunanya percaya. Dalam rangka memenuhi kepercayaan pengguna, $e$-wallet didukung dengan keamanan yang tinggi. Setiap masuk aplikasi e-wallet, pengguna diminta untuk memasukkan pin sebagai verifikasi bahwa tidak ada orang lain yang menyalahgunakan penggunaan aplikasi tersebut.

Banjarmasin adalah salah satu dari 10 Kota Metropolis di Indonesia, dengan jumlah penduduk 715.703 Jiwa dan Pendapatan Asli Daerah (PAD) sebesar 297 Milyar. Pemerintah Kota Banjarmasin terus mempopulerkan penggunaan transaksi non-tunai di daerahnya, salah satu cara yang dilakukan adalah dengan membangun ewarung. Pertumbuhan transaksi non tunai semakin meningkat, hal ini terlihat dari

merchant QRIS (Quick Response Indonesian Standard) secara nasional berjumlah 4.450.231, Kalimantan Selatan (Kalsel) berkontribusi 0,86 persen. Salah satu kota di Kalimantan Selatan yang memiliki merchant QRIS terbanyak adalah Banjarmasin.

Tren pembayaran digital melalui metode QRIS mulai digandrungi pelaku UMKM di Kota Banjarmasin. Ditambah lagi dengan situasi pandemi Covid-19, mereka menilai transaksi dengan cara ini lebih mudah dan aman dari penularan Virus Corona. Salah satu metode pembayaran yang digunakan pada merchant QRIS adalah $e$-Wallet (Dompet Digital).

Kehadiran E-Wallet di Banjarmasin, di awali sejak hadirnya salah satu penyedia E-Wallet yaitu Gopay dari gojek yang beroperasi sejak tahun 2017 yang kemudian disusul oleh OVO, dan lain-lain. Begitu juga $E$ Wallet dari perusahaan plat merah milik pemerintah LINK aja juga sudah hadir di Banjarmasin. Hingga saat ini menurut Kepala Perwakilan Bank Indonesia Banjarmasin, ada sekitar 22.500 merchant atau pedagang yang menggunakan QRIS yang salah satu pembayarannya menggunakan E-Wallet.

\section{Studi Literatur}


Menurut Kotler dan Keller (2012:5), Pemasaran mempunyai fungsi strategis yang sangat besar dalam menjalankan aktivitas bisnis untuk mencapai keberhasilan sebuah perusahaan. Melalui pemasaran, produk dapat dikenal oleh konsumen. Manajemen pemasaran adalah seni dan ilmu memilih pasar sasaran, mendapatkan, mempertahankan, dan menumbuhkan pelanggan melalui penciptaan, pengiriman, dan mengomunikasikan nilai pelanggan yang unggul.

Promosi merupakan suatu bagian rangkaian kegiatan pemasaran suatu produk. Kegiatan promosi adalah segala sesuatu yang dilakukan penjual untuk memperkenalkan produk kepada calon konsumen dan membujuk mereka untuk membeli dan mengingatkan kembali konsumen lama agar melakukan pembelian ulang.

Alat promosi yang sering digunakan dalam mengkomunikasikan produk menurut Philip Kotler dan Gary Armstrong, (2012:643) adalah : Periklanan (Advertising), Penjualan Personal (Personal Selling), Pemasaran Langsung (Direct Selling) dan Promosi Penjualan (Sales Promotion)

Salah satu model yang digunakan untuk menganalisis factorfaktor yang mempengaruhi diterimanya suatu system informasi adalah model Technology Acceptance Model (TAM). TAM memiliki lima konstruk utama, yaitu: Perceive usefulness (persepsi kegunaan), Perceive ease of use (persepsi kemudahan), Attitude towards behavior (sikap terhadap perilaku), Behavioral intention (Niat perilaku) dan Actual technology use (penggunaan teknologi sesungguhnya).

Persepsi kemudahan sangat menentukan diterima atau tidaknya suatu teknologi. Menurut Jimenez et al., dalam penelitian I Made Bayu Dirgantara (2017:4) mengemukakan bahwa persepsi kemudahan penggunaan terdiri dari tiga indikator, yaitu: Mudah untuk dipelajari, Mudah untuk didapatkan dan Mudah untuk dioperasikan.

Selain karena adanya kemudahan, manfaat yang dirasakan oleh pengguna juga akan menentukan penerimaan terhadap suatu teknologi. Menurut Jogiyanto dalam Ferry Wibowo, Dede Rosmauli, dan Usep Suhud (2015:444) mengemukakan bahwa terdapat empat item dimensi dari persepsi manfaat : Produktivitas (Productivity), Kinerja Pekerjaan atau efektivitas (Job performance or effectiveness), Pentingnya bagi tugas (importance to job), Kebermanfaatan secara keseluruhan (overall usefulness).

Faktor kepercayaan juga sangat menentukan dan menjadi pertimbangan dalam penggunaan suatu teknologi. Kepercayaan adalah keinginan satu pihak untuk mendapatkan perlakuan dari pihak lainnya dengan harapan bahwa pihak lainya akan melakukan tindakan penting untuk memenuhi harapan tersebut, terlepas dari kemampuannya untuk memonitor atau mengontrol pihak lain. Kepercayaan merupakan produk yang dihasilkan diantara kedua pelaku dalam suatu pertukaran dengan lebih memperdulikan biaya dan manfaat dari perilaku tertentu sebagaimana diatur dalam kontrak. Dengan kata lain, kepercayaan adalah sebuah belief, sebuah perasaan, atau suatu harapan terhadap pihak lainnya yang merupakan keahlian, keandalan, dan perhatian pihak lainya, atau the perception of confidence in the exchange partner's reliability and integrity (Soegoto; 2014; 273).

Menurut Darwin dan Konto (2014:3), Terdapat lima dimensi yang membentuk kepercayaan pelanggan, antara lain : Benevolence yakni itikat baik dan keyakinan bahwa suatu pihak akan dilindungi dan tidak akan dirugikan oleh pihak yang dipercayai, kemudian Reliability atau kemampuan 
dapat diandalkan untuk memenuhi sesuatu yang dibutuhkan oleh seseorang atau kelompok apabila mereka membutuhkan. Selanjutnya Competence atau kemampuan yang dimiliki oleh suatu pihak dari segi skill dan pengetahuan yang dimiliki untuk memenuhi kebutuhan pelanggan, kemudian Honesty atau sejauh mana pernyataan atau ungkapan dapat ditepati dan dimensi yang terakhir adalah Openness atau keterbukaan untuk memberitakan atau memberikan informasi yang dibutuhkan kepada pelanggan.

Minat

merupakan kencenderungan dan kegairahan yang tinggi atau keinginan yang besar terhadap sesuatu. Istilah minat sendiri merupakan terminology aspek kepribadian untuk mengkan adanya kemauan, dorongan (force) yang timbul dari dalam diri individu untuk memilih obyek lain yang sejenis (Muhibbin, 2010:133).

Indikator minat menurut Walgito dalam Rodiah (2020:36) terdiri dari tiga indikator. Indikator inilah yang peneliti pakai dalam penelitian minat menggunakan, dari ketiga indikator tersebut yaitu: Ketertarikan pada obyek minat, yaitu calon konsumen atau konsumen memiliki perhatian yang selalu tertuju dan terpusat pada e-wallet, selanjutnya Perasaan senang, yaitu calon konsumen atau konsumen yang berminat untuk menggunakan terlihat memiliki perasaan senang dalam menggunakan. Dan Indikator yang terakhir adalah Kecenderungan untuk menggunakan, yaitu sering tidaknya calon konsumen atau konsumen berkeinginan untuk menggunakan e-wallet dalam bertransaksi sehari-hari. Konsumen yang minat menggunakannya tinggi akan terlihat dari frekuensinya dalam menggunakan e-wallet yang tinggi.

\section{Metode Penelitian}

Penelitian ini dilakukan di Kota Banjarmasin, dengan populasi pada penelitian ini adalah masyarakat pengguna e-wallet di Kota Banjarmasin, yang jumlahnya tidak diketahui secara pasti jumlah keseluruhan populasi yang menggunakan e-wallet. Karena jumlah populasi pada penelitian ini tidak diketahui secara pasti. maka penentuan jumlah sampel menggunakan rumus Lemeshow, sehingga diperoleh jumlah sampel sebanyak 100 responden.

Teknik pengambilan sampel mengggunakan Sampling Purposive yaitu teknik penentuan sampel dengan pertimbangan tertentu. Jenis teknik ini paling cocok untuk penelitian ini dikarenakan dengan menggunakan teknik Sampling Purposive, peneliti dapat menentukan sampel dengan kriteria tertentu sehingga sampel yang dipilih merupakan sampel yang relevan dan akan memberikan jawaban yang objektif. Kriteria sampel pada penelitian ini yaitu: Memiliki akun e-Wallet, baik aplikasi langsung, maupun pada aplikasi merchant, kemudian pernah melakukan top-up di akun e-Wallet dan yang ketiga telah melakukan pembayaran dengan eWallet lebih dari satu kali.

Variabel pada penelitian ini adalah tiga variabel independen yaitu promosi (X1), persepsi kemudahan (X2) dan persepsi manfaat (X3), satu variabel dependen yaitu minat penggunaan $(\mathrm{Z})$ dan satu variabel mediasi yaitu kepercayaan (Y). Pengukuran variabel mengunakan skala likert yang digunakan untuk mengukur sikap, pendapat, dan persepsi seseorang atau sekelompok orang tentang fenomena sosial. Skala likert mempunyai gradasi dari sangat positif sampai sangat negative yang berupa kata-kata sebagai berikut: Sangat Setuju, Setuju, Ragu-ragu, Tidak Setuju, Sangat Tidak Setuju. 
Teknik analisis data yang digunakan adalah SEM (Structural Equation Modeling) untuk mengetahui hubungan antar variabel dengan aplikasi AMOS 24 dan Uji Sobel untuk mengetahui peran mediasi, dengan langkah-langkah sebagai berikut :

1. Uji Instrumen : Validitas dan Reabilitas

2. Uji Hipotesis :
a. Evaluasi
Asumsi
Model : Normalitas Data, Outliers, Multikolineritas dan Singularitas

b. Analisis Full Model dan Persamaan Struktural

c. Interpretasi Model atau hasil Pengujian

3. Uji Mediasi/SOBEL test

\section{Hasil Penelitian dan Pembahasan}

Responden dalam penelitian ini adalah masyarakat yang berada dalam wilayah Kota Banjarmasin yang berusia produktif atau berusia 15-64 tahun dan menjadi pengguna aktif e-wallet. Sebagaimana yang tergambar pada grafik berikut ini:

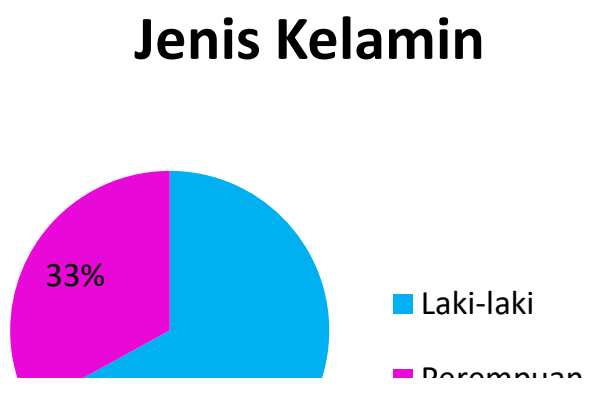

\section{Usia Responden}

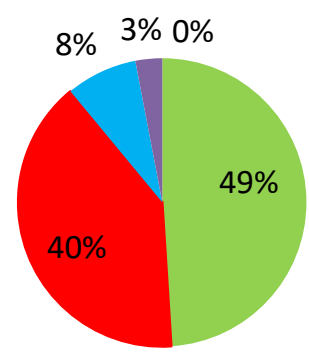

$$
\begin{array}{r}
\square 15-24 \\
\square 25-34 \\
\square 35-44 \\
\square 45-54 \\
\square 55-64
\end{array}
$$

\section{Jenis Pekerjaan}

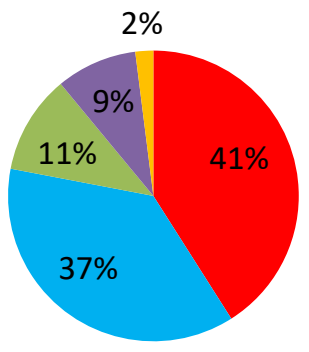

- Pelajar/Mahasiswa

Karyawan Swasta

PNS/TNI/Polisi

Wiraswasta/Pedagang

- Lainnya

Analisis deskriptif data penelitian dapat digunakan untuk memperkaya pembahasan, melalui analisis ini dapat diketahui bagaimana tanggapan responden terhadap setiap indikator variabel yang sedang diteliti. Agar lebih mudah menginterpretasikan variabel yang sedang diteliti, maka dilakukan kategorisasi terhadap skor tanggapan responden.

\begin{tabular}{|c|c|}
\hline Interval & Interpretasi \\
\hline $1,00-1.79$ & Sangat Rendah \\
\hline $1,80-2.59$ & Rendah \\
\hline $2,60-3,39$ & Sedang \\
\hline $3,40-4,19$ & Tinggi \\
\hline $4,20-5,00$ & Sangat Tinggi \\
\hline
\end{tabular}

Sumber : data diolah

\begin{tabular}{|c|c|c|c|c|c|c|}
\hline $\begin{array}{c}\text { Di } \\
\text { me } \\
\text { nsi }\end{array}$ & $\begin{array}{c}\text { Mini } \\
\text { mu } \\
\text { m }\end{array}$ & $\begin{array}{c}\text { Max } \\
\text { imu } \\
\text { m }\end{array}$ & $\begin{array}{c}\text { M } \\
\text { ea } \\
\text { n }\end{array}$ & $\begin{array}{c}\text { Std. } \\
\text { Deviat } \\
\text { ion }\end{array}$ & $\begin{array}{c}\text { Mean } \\
\text { per } \\
\text { dimensi }\end{array}$ & $\begin{array}{c}\text { Mean } \\
\text { per } \\
\text { variabel }\end{array}$ \\
\hline \multirow{2}{*}{ X1 } & 2 & 5 & $\begin{array}{c}3 . \\
89\end{array}$ & 0.634 & & \\
1 & & & 0 & & & \\
\cline { 2 - 4 } & 2 & 5 & $\begin{array}{c}3 . \\
86\end{array}$ & 0.620 & & \\
& & & & & & \\
& & & & & & \\
\end{tabular}




\begin{tabular}{|c|c|c|c|c|c|}
\hline \multirow{2}{*}{$\begin{array}{c}\mathrm{X} 1 \\
2\end{array}$} & 2 & 5 & $\begin{array}{c}3 . \\
77 \\
0\end{array}$ & 0.680 & \multirow{2}{*}{3.775} \\
\hline & 2 & 5 & $\begin{array}{c}3 . \\
78 \\
0\end{array}$ & 0.719 & \\
\hline \multirow{2}{*}{$\begin{array}{c}\mathrm{X} 1 \\
3\end{array}$} & 1 & 5 & $\begin{array}{c}3 . \\
91 \\
0\end{array}$ & 0.653 & \multirow{2}{*}{3.840} \\
\hline & 2 & 5 & $\begin{array}{c}3 . \\
77 \\
0\end{array}$ & 0.723 & \\
\hline \multirow{2}{*}{$\begin{array}{c}\mathrm{X} 1 \\
4\end{array}$} & 3 & 5 & $\begin{array}{c}4 . \\
24 \\
0\end{array}$ & 0.605 & \multirow{2}{*}{4.150} \\
\hline & 3 & 5 & $\begin{array}{c}4 . \\
06 \\
0\end{array}$ & 0.547 & \\
\hline
\end{tabular}

Sumber : data diolah

Berdasarkan table di atas, mean skor per dimensi terendah adalah 3,775 yaitu X12; mean skor tertinggi adalah 4,150 yaitu X14 dengan mean per variabel nya 3,910. Hal ini menunjukkan bahwa jawaban responden pada variabel Promosi ini adalah tinggi karena berada diantara 3,40 - 4,19.

\begin{tabular}{|c|c|c|c|c|c|c|}
\hline $\begin{array}{l}\text { Di } \\
\text { me } \\
\text { nsi }\end{array}$ & $\begin{array}{c}\text { Mini } \\
\text { mu } \\
\text { m }\end{array}$ & $\begin{array}{c}\text { Max } \\
\text { imu } \\
\text { m }\end{array}$ & $\begin{array}{c}\text { M } \\
\text { ea } \\
\mathbf{n}\end{array}$ & $\begin{array}{c}\text { Std. } \\
\text { Deviat } \\
\text { ion }\end{array}$ & $\begin{array}{c}\text { Mean } \\
\text { per } \\
\text { dimensi }\end{array}$ & $\begin{array}{c}\text { Mean } \\
\text { per } \\
\text { variabel }\end{array}$ \\
\hline \multirow{2}{*}{$\begin{array}{c}\mathrm{X} 2 \\
1\end{array}$} & 2 & 5 & $\begin{array}{c}4 . \\
03 \\
0\end{array}$ & 0.559 & \multirow{2}{*}{4.020} & \multirow{6}{*}{3.928} \\
\hline & 3 & 5 & $\begin{array}{c}4 . \\
01 \\
0\end{array}$ & 0.541 & & \\
\hline \multirow{2}{*}{$\begin{array}{c}X 2 \\
2\end{array}$} & 1 & 5 & $\begin{array}{c}3 . \\
80 \\
0 \\
\end{array}$ & 0.696 & \multirow{2}{*}{3.815} & \\
\hline & 2 & 5 & $\begin{array}{c}3 . \\
83 \\
0\end{array}$ & 0.792 & & \\
\hline \multirow{2}{*}{$\begin{array}{c}X 2 \\
3\end{array}$} & 3 & 5 & $\begin{array}{c}4 . \\
03 \\
0\end{array}$ & 0.594 & \multirow{2}{*}{3.950} & \\
\hline & 2 & 5 & $\begin{array}{c}3 . \\
87 \\
0\end{array}$ & 0.630 & & \\
\hline
\end{tabular}

Sumber : data diolah

Berdasarkan table di atas, mean skor per dimensi terendah adalah 3,815 yaitu X22; mean skor tertinggi adalah 4,020 yaitu X21 dengan mean per variabel nya 3,928 . Hal ini menunjukkan bahwa jawaban responden pada variabel Persepsi Kemudahan ini adalah tinggi karena berada diantara 3,40 - 4,19.

\begin{tabular}{|c|c|c|c|c|c|c|}
\hline $\begin{array}{l}\text { Di } \\
\text { me } \\
\text { nsi }\end{array}$ & $\begin{array}{c}\text { Mini } \\
\text { mu } \\
\text { m }\end{array}$ & $\begin{array}{c}\text { Max } \\
\text { imu } \\
\text { m }\end{array}$ & $\begin{array}{c}\text { M } \\
\text { ea } \\
\mathbf{n}\end{array}$ & $\begin{array}{c}\text { Std. } \\
\text { Deviat } \\
\text { ion }\end{array}$ & $\begin{array}{l}\text { Mean } \\
\text { per } \\
\text { dimensi }\end{array}$ & $\begin{array}{c}\text { Mean } \\
\text { per } \\
\text { variabel }\end{array}$ \\
\hline \multirow{2}{*}{$\begin{array}{c}\text { X3 } \\
1\end{array}$} & 2 & 5 & $\begin{array}{c}4 . \\
12 \\
0\end{array}$ & 0.591 & \multirow{2}{*}{4.020} & \multirow{8}{*}{3.936} \\
\hline & 1 & 5 & $\begin{array}{c}3 . \\
92 \\
0\end{array}$ & 0.677 & & \\
\hline \multirow{2}{*}{$\begin{array}{c}\mathrm{X} 3 \\
2\end{array}$} & 2 & 5 & $\begin{array}{c}3 . \\
92 \\
0\end{array}$ & 0.646 & \multirow{2}{*}{3.900} & \\
\hline & 3 & 5 & $\begin{array}{c}3 . \\
88 \\
0\end{array}$ & 0.640 & & \\
\hline \multirow{2}{*}{$\begin{array}{c}\mathrm{X} 3 \\
3\end{array}$} & 3 & 5 & $\begin{array}{c}3 . \\
95 \\
0\end{array}$ & 0.575 & \multirow{2}{*}{3.885} & \\
\hline & 3 & 5 & $\begin{array}{c}3 . \\
82 \\
0 \\
\end{array}$ & 0.593 & & \\
\hline \multirow{2}{*}{$\begin{array}{c}\mathrm{X} 3 \\
4\end{array}$} & 2 & 5 & $\begin{array}{c}4 . \\
00 \\
0\end{array}$ & 0.512 & \multirow{2}{*}{3.940} & \\
\hline & 1 & 5 & $\begin{array}{c}3 . \\
88 \\
0\end{array}$ & 0.700 & & \\
\hline
\end{tabular}

Sumber : data diolah

Berdasarkan table di atas, mean skor per dimensi terendah adalah 3,885 yaitu X33; mean skor tertinggi adalah 4,020 yaitu X31 dengan mean per variabel nya 3,936. Hal ini menunjukkan bahwa jawaban responden pada variabel Persepsi Manfaati ini adalah tinggi karena berada diantara 3,40 - 4,19.

\begin{tabular}{|c|c|c|c|c|c|c|}
\hline $\begin{array}{l}\text { Dim } \\
\text { ensi }\end{array}$ & $\begin{array}{l}\text { Mini } \\
\text { mum }\end{array}$ & $\begin{array}{l}\text { Maxi } \\
\text { mum }\end{array}$ & $\begin{array}{c}\text { M } \\
\text { ea } \\
\mathbf{n}\end{array}$ & $\begin{array}{c}\text { Std. } \\
\text { Deviati } \\
\text { on }\end{array}$ & $\begin{array}{c}\text { Mean per } \\
\text { dimensi }\end{array}$ & $\begin{array}{c}\text { Mean per } \\
\text { variabel }\end{array}$ \\
\hline \multirow{2}{*}{$Y 1$} & 3 & 5 & $\begin{array}{c}3.9 \\
10\end{array}$ & 0.494 & \multirow{2}{*}{3.915} & \multirow{10}{*}{3.912} \\
\hline & 2 & 5 & $\begin{array}{l}3.9 \\
20 \\
\end{array}$ & 0.614 & & \\
\hline \multirow{2}{*}{$Y 2$} & 2 & 5 & $\begin{array}{l}3.9 \\
50\end{array}$ & 0.575 & \multirow{2}{*}{3.905} & \\
\hline & 2 & 5 & $\begin{array}{c}3.8 \\
60\end{array}$ & 0.652 & & \\
\hline \multirow{2}{*}{$Y 3$} & 2 & 5 & $\begin{array}{l}3.9 \\
30 \\
\end{array}$ & 0.590 & \multirow{2}{*}{3.930} & \\
\hline & 1 & 5 & $\begin{array}{l}3.9 \\
30 \\
\end{array}$ & 0.671 & & \\
\hline \multirow{2}{*}{$Y 4$} & 3 & 5 & $\begin{array}{l}3.9 \\
70\end{array}$ & 0.502 & \multirow{2}{*}{3.915} & \\
\hline & 2 & 5 & $\begin{array}{l}3.8 \\
60 \\
\end{array}$ & 0.636 & & \\
\hline \multirow{2}{*}{$Y 5$} & 2 & 5 & $\begin{array}{l}3.9 \\
30 \\
\end{array}$ & 0.573 & \multirow{2}{*}{3.895} & \\
\hline & 2 & 5 & $\begin{array}{l}3.8 \\
60\end{array}$ & 0.636 & & \\
\hline
\end{tabular}

Sumber : data diolah

Berdasarkan table di atas, mean skor per dimensi terendah adalah 3,895 yaitu Y5; mean skor tertinggi adalah 3,930 yaitu Y3 dengan mean per variabel nya 3,912 . Hal ini 
menunjukkan bahwa jawaban responden pada variabel Kepercayaan ini adalah tinggi karena berada diantara 3,40 - 4,19.

\begin{tabular}{|c|c|c|c|c|c|c|}
\hline $\begin{array}{l}\text { Di } \\
\text { me } \\
\text { nsi }\end{array}$ & $\begin{array}{c}\text { Mini } \\
\text { mu } \\
\text { m }\end{array}$ & $\begin{array}{c}\text { Max } \\
\text { imu } \\
\text { m }\end{array}$ & $\begin{array}{c}\text { M } \\
\text { ea } \\
\text { n }\end{array}$ & $\begin{array}{c}\text { Std. } \\
\text { Deviat } \\
\text { ion }\end{array}$ & $\begin{array}{c}\text { Mean } \\
\text { per } \\
\text { dimensi }\end{array}$ & $\begin{array}{c}\text { Mean } \\
\text { per } \\
\text { variabel }\end{array}$ \\
\hline \multirow{2}{*}{$\mathrm{Z} 1$} & 3 & 5 & $\begin{array}{c}4 . \\
06 \\
0\end{array}$ & 0.547 & \multirow{2}{*}{3.970} & \multirow{6}{*}{3.927} \\
\hline & 1 & 5 & $\begin{array}{c}3 . \\
88 \\
0\end{array}$ & 0.656 & & \\
\hline \multirow{2}{*}{$\mathrm{Z} 2$} & 2 & 5 & $\begin{array}{c}4 . \\
01 \\
0\end{array}$ & 0.595 & \multirow{2}{*}{3.945} & \\
\hline & 2 & 5 & $\begin{array}{c}3 . \\
88 \\
0 \\
\end{array}$ & 0.591 & & \\
\hline \multirow[b]{2}{*}{$\mathrm{Z3}$} & 2 & 5 & $\begin{array}{c}3 . \\
79 \\
0\end{array}$ & 0.729 & \multirow[b]{2}{*}{3.865} & \\
\hline & 2 & 5 & $\begin{array}{c}3 . \\
94 \\
0\end{array}$ & 0.633 & & \\
\hline
\end{tabular}

Sumber : data diolah

Berdasarkan table di atas, mean skor per dimensi terendah adalah 3,865 yaitu Z3; mean skor tertinggi adalah 3,970 yaitu Z1 dengan mean per variabel nya 3,927 . Hal ini menunjukkan bahwa jawaban responden pada variabel Kepercayaan ini adalah tinggi karena berada diantara 3,40 4,19 .

\section{Uji Instrumen}

\section{Hasil Uji Validitas}

a. Hasil Uji Validitas Variabel Promosi (X1)

\begin{tabular}{|c|c|c|c|c|}
\hline \multicolumn{2}{|c|}{ Indikator } & $\begin{array}{r}\text { Esti } \\
\text { mate }\end{array}$ & $\begin{array}{c}\text { P- } \\
\text { Val }\end{array}$ & $\begin{array}{l}\text { Ketera } \\
\text { noan }\end{array}$ \\
\hline & $\begin{array}{ll}<- & X \\
- & 1\end{array}$ & $\begin{array}{r}0.73 \\
9\end{array}$ & $* * *$ & Valid \\
\hline $\mathrm{X} 1$ & $<--\quad X$ & 0.81 & $* *$ & Valid \\
\hline & $\begin{array}{ll}- & 1\end{array}$ & 9 & $*$ & \\
\hline $\mathrm{X} 1$ & $<--\quad X$ & 0.74 & $* *$ & Valid \\
\hline 3 & $\begin{array}{ll}- & 1\end{array}$ & 9 & $*$ & \\
\hline $\mathrm{X} 1$ & $<--\quad X$ & 0.69 & $* *$ & Valid \\
\hline 4 & $\begin{array}{ll}- & 1\end{array}$ & 5 & $*$ & \\
\hline
\end{tabular}

nilai lebih rendah dari 0,000
Sumber : data diolah

b. Hasil Uji Validitas Variabel Persepsi Kemudahan (X2)

\begin{tabular}{|c|c|c|c|}
\hline Indikator & $\begin{array}{r}\text { Esti } \\
\text { mate }\end{array}$ & $\begin{array}{r}\text { P- } \\
\text { Val } \\
\text { ue }\end{array}$ & $\begin{array}{l}\text { Ketera } \\
\text { ngan }\end{array}$ \\
\hline X2 $<--\quad X$ & 0.78 & $* * *$ & Valid \\
\hline $\begin{array}{llll} & - & \\
X 2 & <- & X \\
2 & - & 2\end{array}$ & $\begin{array}{r}0.70 \\
2\end{array}$ & $* * *$ & Valid \\
\hline $\begin{array}{lll}X 2 & <- & X \\
3 & - & 2\end{array}$ & $\begin{array}{r}0.78 \\
3\end{array}$ & $* * *$ & V alld \\
\hline
\end{tabular}

c. Hasil Uji Validitas Variabel Persepsi Manfaat (X3)

\begin{tabular}{|c|c|c|c|c|}
\hline \multicolumn{2}{|c|}{ Indikator } & \multirow{2}{*}{$\begin{array}{c}\begin{array}{c}\text { Esti } \\
\text { mate }\end{array} \\
0.81\end{array}$} & $\begin{array}{r}\text { P- } \\
\text { Val } \\
\text { ue }\end{array}$ & $\begin{array}{l}\text { Ketera } \\
\text { ngan }\end{array}$ \\
\hline & $<--\quad X$ & & $* * *$ & Ylid \\
\hline 1 & $\begin{array}{l}-\quad 3 \\
-\end{array}$ & 6 & 4. & valla \\
\hline X3 & $<--\quad X$ & 0.75 & $* * *$ & Valid \\
\hline 2 & $\begin{array}{l}-\quad 3 \\
-\quad 1\end{array}$ & 9 & & \\
\hline X3 & $<--\quad X$ & 0.62 & $* * *$ & Valid \\
\hline 3 & 3 & 4 & & \\
\hline X3 & $<-\quad X$ & 0.81 & $* * *$ & Valid \\
\hline 4 & - & 5 & & \\
\hline
\end{tabular}
nilai lebih rendah dari 0,000

Sumber : data diolah

d. Hasil Uji Validitas Variabel Kepercayaan (Y)

\begin{tabular}{|c|c|c|c|c|c|}
\hline \multicolumn{3}{|c|}{ Indikator } & \multirow{2}{*}{$\begin{array}{r}\begin{array}{r}\text { Estim } \\
\text { ate }\end{array} \\
0.806\end{array}$} & \multirow{2}{*}{$\begin{array}{r}\mathrm{P}- \\
\mathrm{Val} \\
\mathrm{ue} \\
* * *\end{array}$} & \multirow{2}{*}{$\begin{array}{l}\begin{array}{l}\text { Keteran } \\
\text { gan }\end{array} \\
\text { Valid }\end{array}$} \\
\hline $\begin{array}{l}\mathrm{Y} \\
1\end{array}$ & $\begin{array}{l}<- \\
-\end{array}$ & $\mathrm{Y}$ & & & \\
\hline $\begin{array}{l}Y \\
2\end{array}$ & $\begin{array}{l}<- \\
-\end{array}$ & $\mathrm{Y}$ & 0.853 & $* * *$ & Valid \\
\hline $\begin{array}{l}Y \\
3\end{array}$ & $\begin{array}{l}<- \\
-\end{array}$ & $\mathrm{Y}$ & 0.732 & $* * *$ & Valid \\
\hline $\begin{array}{l}Y \\
4\end{array}$ & $\begin{array}{l}<- \\
-\end{array}$ & $\mathrm{Y}$ & 0.810 & $* * *$ & Valid \\
\hline $\begin{array}{l}Y \\
5\end{array}$ & $\begin{array}{l}<- \\
-\end{array}$ & $\mathrm{Y}$ & 0.818 & $* * *$ & Valid \\
\hline
\end{tabular}

nilai lebih rendah dari 0,000

Sumber : data diolah 
e. Hasil Uji Validitas Variabel Minat Penggunaan

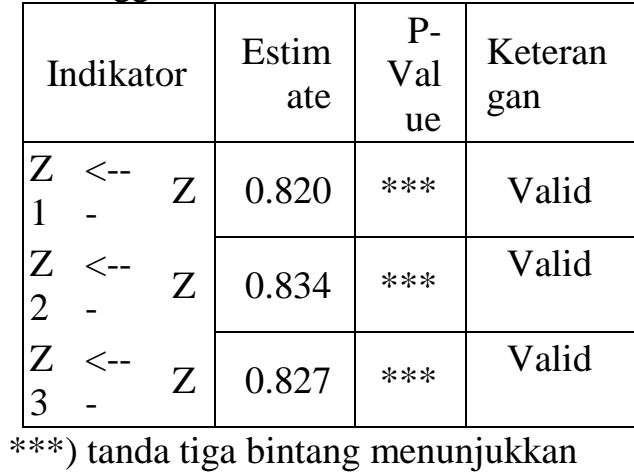
nilai lebih rendah dari 0,000

Sumber : data diolah

Berdasarkan hasil yang diperoleh dari pengujian validitas penelitian pada table di atas, karena diperoleh nilai standardized loading estimate yang lebih besar dari 0,5 dengan $\mathrm{p}$ lebih kecil dari nilai 0,05. Dengan demikian dapat dinyatakan bahwa semua indikator dapat dinyatakan valid..

\section{Hasil Uji Reabilitas}

\begin{tabular}{|l|c|c|}
\hline Variabel & $\begin{array}{c}\text { Construc } \\
\mathrm{t} \\
\text { reliabilit } \\
\mathrm{y}\end{array}$ & $\begin{array}{c}\text { Keteranga } \\
\mathrm{n}\end{array}$ \\
\hline $\begin{array}{l}\text { Promosi } \\
(\mathrm{X} 1)\end{array}$ & 0.838 & Reliabel \\
\hline $\begin{array}{l}\text { Persepsi } \\
\text { Kemudahan } \\
(\mathrm{X} 2)\end{array}$ & 0.800 & Reliabel \\
\hline $\begin{array}{l}\text { Persepsi } \\
\text { Manfaat } \\
(\mathrm{X} 3)\end{array}$ & 0.905 & Reliabel \\
\hline $\begin{array}{l}\text { Kepercayaa } \\
\mathrm{n}(\mathrm{Y})\end{array}$ & 0.902 & Reliabel \\
\hline $\begin{array}{l}\text { Minat } \\
\text { Penggunaan } \\
(\mathrm{Z})\end{array}$ & 0.867 & Reliabel \\
\hline
\end{tabular}

Sumber : data diolah

Berdasarkan hasil yang diperoleh dari pengujian reliabilitas instrumen penelitian pada table di atas, karena diperoleh nilai koefisien reliabilitas construct reliability $>0,7$ maka dapat dinyatakan bahwa instrumen penelitian tersebut telah reliabel.

\section{Uji Hipotesis}

\section{Pengujian Evaluasi Asumsi Model Struktural}

Model persamaan struktural yang baik yaitu model yang mampu memenuhi setiap asumsi yang ada. Oleh karena itu, sebelum melakukan pembahasan terkait hipotesis pada masing-masing model, perlu dilihat terlebih dahulu asumsiasumsi model persamaan struktutral.

a. Evaluasi Atas Asumsi Normalitas Data

\begin{tabular}{|c|c|c|c|c|c|c|}
\hline $\begin{array}{l}\text { Varia } \\
\text { ble }\end{array}$ & $\begin{array}{r}\mathrm{mi} \\
\mathrm{n}\end{array}$ & $\begin{array}{c}\mathrm{m} \\
\mathrm{ax}\end{array}$ & $\begin{array}{r}\text { sk } \\
\text { e } \\
\text { w }\end{array}$ & & $\begin{array}{r}\text { kur } \\
\text { tosi } \\
\mathrm{s}\end{array}$ & c.r \\
\hline Z3 & $\begin{array}{r}2, \\
00 \\
0\end{array}$ & $\begin{array}{r}5, \\
00 \\
0\end{array}$ & $\begin{array}{r}\text {,4 } \\
90\end{array}$ & $\begin{array}{r}- \\
2,0 \\
01\end{array}$ & $\begin{array}{r}, 45 \\
4\end{array}$ & $\begin{array}{r}, 9 \\
26\end{array}$ \\
\hline Z2 & $\begin{array}{r}2, \\
50 \\
0\end{array}$ & $\begin{array}{r}5, \\
00 \\
0\end{array}$ & $\begin{array}{r}, 1 \\
45\end{array}$ & $\begin{array}{r}, 59 \\
0\end{array}$ & $\begin{array}{r}33 \\
9\end{array}$ & $\begin{array}{r}6 \\
93\end{array}$ \\
\hline Z1 & $\begin{array}{r}2, \\
50 \\
0\end{array}$ & $\begin{array}{r}5, \\
00 \\
0\end{array}$ & $\begin{array}{r}, 1 \\
20\end{array}$ & $\begin{array}{r}48 \\
9\end{array}$ & $\begin{array}{r}67 \\
4\end{array}$ & $\begin{array}{r}1, \\
37 \\
6\end{array}$ \\
\hline Y5 & $\begin{array}{r}2, \\
50 \\
0\end{array}$ & $\begin{array}{r}5, \\
00 \\
0\end{array}$ & $\begin{array}{r}1 \\
57\end{array}$ & $\begin{array}{r}- \\
, 64 \\
3\end{array}$ & $\begin{array}{r}, 50 \\
5\end{array}$ & $\begin{array}{r}1, \\
03 \\
1\end{array}$ \\
\hline Y4 & $\begin{array}{r}2, \\
50 \\
0\end{array}$ & $\begin{array}{r}5, \\
00 \\
0\end{array}$ & $\begin{array}{r}, 0 \\
32\end{array}$ & $\begin{array}{r}13 \\
2\end{array}$ & $\begin{array}{r}, 72 \\
5\end{array}$ & $\begin{array}{r}1, \\
48 \\
0\end{array}$ \\
\hline Y3 & $\begin{array}{r}2, \\
50 \\
0\end{array}$ & $\begin{array}{r}5, \\
00 \\
0\end{array}$ & $\begin{array}{r}- \\
59 \\
59\end{array}$ & $\begin{array}{r}1,4 \\
67\end{array}$ & $\begin{array}{r}, 51 \\
8\end{array}$ & $\begin{array}{r}1, \\
05 \\
8\end{array}$ \\
\hline Y2 & $\begin{array}{r}2, \\
50 \\
0\end{array}$ & $\begin{array}{r}5, \\
00 \\
0\end{array}$ & $\begin{array}{r}, 0 \\
64\end{array}$ & $\begin{array}{r}, 26 \\
0\end{array}$ & $\begin{array}{r}, 84 \\
3\end{array}$ & $\begin{array}{r}1, \\
72 \\
1\end{array}$ \\
\hline Y1 & $\begin{array}{r}2, \\
50 \\
0\end{array}$ & $\begin{array}{r}5, \\
00 \\
0\end{array}$ & $\begin{array}{l}, 1 \\
83\end{array}$ & $\begin{array}{r}- \\
, 74 \\
6\end{array}$ & $\begin{array}{r}93 \\
9\end{array}$ & $\begin{array}{r}1, \\
91 \\
6\end{array}$ \\
\hline X34 & $\begin{array}{r}2, \\
50 \\
0\end{array}$ & $\begin{array}{r}5, \\
00 \\
0\end{array}$ & $\begin{array}{r}1 \\
19\end{array}$ & $\begin{array}{r}- \\
, 48 \\
7\end{array}$ & $\begin{array}{r}, 89 \\
6\end{array}$ & $\begin{array}{r}1, \\
82 \\
9\end{array}$ \\
\hline X33 & $\begin{array}{r}3, \\
00 \\
0\end{array}$ & $\begin{array}{r}5, \\
00 \\
0\end{array}$ & $\begin{array}{r}2 \\
24\end{array}$ & $\begin{array}{r}91 \\
5\end{array}$ & $\begin{array}{r}- \\
, 02 \\
9\end{array}$ & $\begin{array}{r}- \\
, 0 \\
60\end{array}$ \\
\hline X32 & $\begin{array}{r}2, \\
50 \\
0\end{array}$ & $\begin{array}{r}5, \\
00 \\
0\end{array}$ & $\begin{array}{r}- \\
, 1 \\
02\end{array}$ & $\begin{array}{r}, 41 \\
6\end{array}$ & $\begin{array}{r}, 23 \\
8\end{array}$ & $\begin{array}{r}, 4 \\
86\end{array}$ \\
\hline X31 & $\begin{array}{r}3, \\
00 \\
0\end{array}$ & $\begin{array}{r}5, \\
00 \\
0\end{array}$ & $\begin{array}{r}, 2 \\
42\end{array}$ & $\begin{array}{r}98 \\
6\end{array}$ & $\begin{array}{r}15 \\
3\end{array}$ & $\begin{array}{r}, 3 \\
12\end{array}$ \\
\hline
\end{tabular}




\begin{tabular}{|c|c|c|c|c|c|c|}
\hline $\begin{array}{l}\text { Varia } \\
\text { ble }\end{array}$ & $\begin{array}{r}\mathrm{mi} \\
\mathrm{n}\end{array}$ & $\begin{array}{l}\mathrm{m} \\
\mathrm{ax}\end{array}$ & $\begin{array}{r}\text { sk } \\
\text { e } \\
\text { w }\end{array}$ & c.r & $\begin{array}{r}\text { kur } \\
\text { tosi } \\
\mathrm{s}\end{array}$ & c.r \\
\hline $\mathrm{X} 23$ & $\begin{array}{r}3, \\
00 \\
0\end{array}$ & $\begin{array}{r}5, \\
00 \\
0\end{array}$ & $\begin{array}{r}, 3 \\
27\end{array}$ & $\begin{array}{r}1,3 \\
33\end{array}$ & $\begin{array}{r}- \\
, 10 \\
2\end{array}$ & $\begin{array}{r}- \\
, 2 \\
09\end{array}$ \\
\hline X22 & $\begin{array}{r}2, \\
00 \\
0\end{array}$ & $\begin{array}{r}5, \\
00 \\
0\end{array}$ & $\begin{array}{r}- \\
, 2 \\
89\end{array}$ & $\begin{array}{r}- \\
1,1 \\
80\end{array}$ & $\begin{array}{r}, 34 \\
7\end{array}$ & $\begin{array}{l}, 7 \\
09\end{array}$ \\
\hline X 21 & $\begin{array}{r}3, \\
00 \\
0\end{array}$ & $\begin{array}{r}5, \\
00 \\
0\end{array}$ & $\begin{array}{l}, 1 \\
95\end{array}$ & $\begin{array}{r}, 79 \\
7\end{array}$ & $\begin{array}{r}, 56 \\
8\end{array}$ & $\begin{array}{r}1, \\
15 \\
9\end{array}$ \\
\hline & 3 , & 5, & - & - & - & - \\
\hline X14 & $\begin{array}{r}00 \\
0\end{array}$ & $\begin{array}{r}00 \\
0\end{array}$ & $\begin{array}{r}1 \\
10\end{array}$ & $\begin{array}{r}, 45 \\
0\end{array}$ & $\begin{array}{r}16 \\
2\end{array}$ & ,3 \\
\hline X13 & $\begin{array}{r}2, \\
00 \\
0\end{array}$ & $\begin{array}{r}5, \\
00 \\
0\end{array}$ & $\begin{array}{r}, 3 \\
82\end{array}$ & $\begin{array}{r}1,5 \\
59\end{array}$ & $\begin{array}{r}, 49 \\
5\end{array}$ & $\begin{array}{r}1, \\
01 \\
1\end{array}$ \\
\hline X12 & $\begin{array}{r}2, \\
00 \\
0\end{array}$ & $\begin{array}{r}5, \\
00 \\
0\end{array}$ & $\begin{array}{r}- \\
.5 \\
14\end{array}$ & $\begin{array}{r}2,1 \\
00\end{array}$ & $\begin{array}{r}38 \\
9\end{array}$ & $\begin{array}{r}, 7 \\
93\end{array}$ \\
\hline $\mathrm{X} 11$ & $\begin{array}{r}2, \\
50 \\
0\end{array}$ & $\begin{array}{r}5, \\
00 \\
0\end{array}$ & $\begin{array}{r}- \\
, 1 \\
39\end{array}$ & $\begin{array}{r}- \\
, 56 \\
9\end{array}$ & $\begin{array}{r}, 02 \\
9\end{array}$ & $\begin{array}{l}, 0 \\
60\end{array}$ \\
\hline $\begin{array}{l}\text { Multi } \\
\text { variat } \\
\mathrm{e}\end{array}$ & & & & & $\begin{array}{r}13, \\
523\end{array}$ & $\begin{array}{r}2, \\
39 \\
4\end{array}$ \\
\hline
\end{tabular}

Sumber : data diolah

Evaluasi normalitas dilakukan dengan menggunakan kriteria critical ratio skewness value dan kurtosis value, yang hasilnya menunjukkan bahwa semua variabel yang terdistribusi normal secara univariate maupun multivariate juga sudah menunjukkan terdistribusi normal. Hal ini ditunjukkan dengan nilai CR skewness dan kurtosis yang berada dibawah \pm 2.58

b. Evaluasi Atas Outliers

\begin{tabular}{|c|ccc|}
\hline $\begin{array}{c}\text { Observation } \\
\text { number }\end{array}$ & $\begin{array}{c}\text { Mahalanobis } \\
\text { d-squared }\end{array}$ & $\mathrm{p} 1$ & $\mathrm{p} 2$ \\
\hline 71 & 32,156 &, 030 &, 952 \\
41 & 31,922 &, 032 &, 832 \\
24 & 31,112 &, 039 &, 757 \\
81 & 31,062 &, 040 &, 565 \\
89 & 29,275 &, 062 &, 747 \\
$\ldots$ & $\ldots$ & & \\
$\ldots$ & $\ldots$ & & \\
\hline
\end{tabular}

Sumber : data diolah

Berdasarkan di atas, nilai Mahalanobis Distance tertinggi adalah 32,156 . Karena nilainya lebih rendah dari $\mathrm{X}^{2}(43,820)$ artinya tidak terdapat outlier.

c. Evaluasi Atas Multikolineritas dan Singularitas

Hasil pengolahan data nilai determinan matriks kovarians sampel adalah:

\section{Determinant of sample \\ covariance matrix $=$ ,000000000000000024}

Dari hasil pengolahan data tersebut dapat diketahui nilai determinant of sample covariance matrix tidak berada cukup dekat dari nol. Hal ini menunjukkan tidak adanya masalah singularitas.

\section{Analisis Full Model Persamaan Struktural \\ Hasil pengolahan data untuk analisis full model persamaan struktural ditampilkan pada berikut ini:}

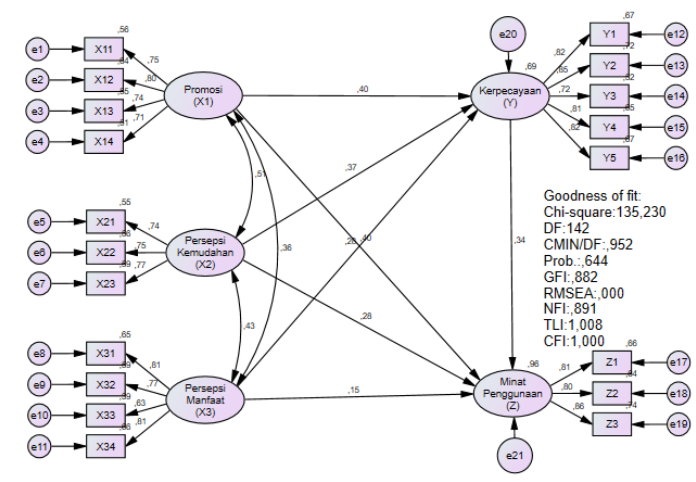

Hasil Indeks Pengujian Analisis Faktor Konfirmatori Full Model Persamaan Struktural

\begin{tabular}{|c|c|c|c|}
\hline $\begin{array}{c}\text { Indeks } \\
\text { Goodness of fit }\end{array}$ & Cut off value & Hasil & Kesimpulan \\
\hline Chi-square & $\begin{array}{c}\leq 170.809 \\
\text { dimana Chi- } \\
\text { square untuk } \\
\text { df } 142 ; \text { taraf } \\
\text { signifikansi } \\
5 \%\end{array}$ & 135.230 & Good fit \\
\hline $\begin{array}{c}\text { Significance } \\
\text { probability (p) }\end{array}$ & $\geq 0.05$ & 0.644 & Good fit \\
\hline CMIN/DF & $\leq 2.00$ & 0.952 & Good fit \\
\hline
\end{tabular}




\begin{tabular}{|c|c|c|c|}
\hline GFI & $\geq 0.90$ & 0.882 & Marginal fit \\
\hline RMSEA & $\leq 0.08$ & 0.000 & Good fit \\
\hline NFI & $\geq 0.90$ & 0.891 & Marginal fit \\
\hline TLI & $\geq 0.90$ & 1.008 & Good fit \\
\hline CFI & $\geq 0.90$ & 1.000 & Good fit \\
\hline
\end{tabular}

Sumber : data diolah

Menunjukkan bahwa Chi-square dalam penelitian ini memiliki nilai sebesar 135,230 yang berarti lebih kecil dari cut off value yang didapat dari Chi-square untuk df 142 dengan taraf signifikansi 5\% yaitu 170,809. Nilai significance probability di atas 0,05 yaitu sebesar 0,644. Oleh karena itu dapat disimpulkan bahwa model tersebut baik. Nilai CMIN/DF, GFI, AGFI, CFI, TLI, dan RMSEA dapat memenuhi kriteria goodness of fit.

\section{Regression Weight Full Model Persamaan} Struktural

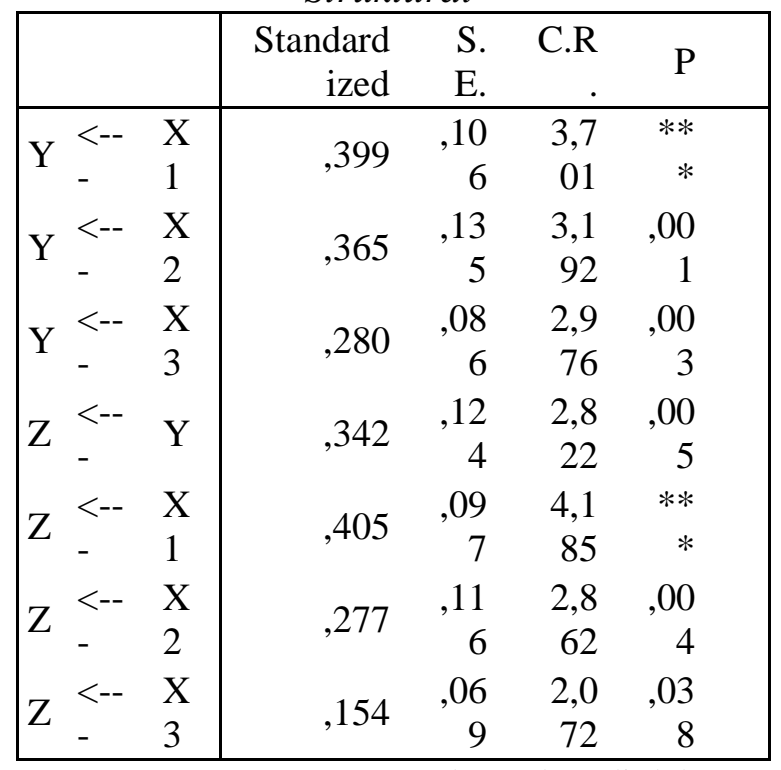

Sumber : data diolah

Berdasarkan table di atas Menunjukkan bahwa model persamaan struktural adalah sebagai berikut:

$$
\begin{gathered}
\mathrm{Y}=0,399 * \mathrm{X} 1+0,365 * \mathrm{X} 2+0,280 * \mathrm{X} 3 \\
\text { Errorvar }=0,310, \mathrm{R}-\text { square }=0,690
\end{gathered}
$$

$$
\begin{gathered}
\mathrm{Z}=0,405 * \mathrm{X} 1+0,277 * \mathrm{X} 2+0,154 * \mathrm{X} 3+* \mathrm{Y} \\
\text { Errorvar }=0,041, \mathrm{R} \text {-square }=0,959
\end{gathered}
$$

Berdasarkan persamaan di atas, dapat disimpulkan sebagai berikut:

Persamaan 1:

1. Koefisien jalur X1 adalah 0,399 dengan arah positif, maka terdapat hubungan yang searah antara X1 dengan Y. Artinya jika X1 meningkat satu satuan maka Y akan meningkat sebesar 0,399 begitu juga sebaliknya.

2. Koefisien jalur X2 adalah 0,365 dengan arah positif, maka terdapat hubungan yang searah antara X2 dengan Y. Artinya jika X2 meningkat satu satuan maka Y akan meningkat sebesar 0,365 begitu juga sebaliknya.

3. Koefisien jalur X3 adalah 0,280 dengan arah positif, maka terdapat hubungan yang searah antara X3 dengan Y. Artinya jika X3 meningkat satu satuan maka Y akan meningkat sebesar 0,280 begitu juga sebaliknya.

4. Nilai $R$ square adalah 0,690 , artinya variable $\mathrm{Y}$ dipengaruhi oleh $\mathrm{X} 1, \mathrm{X} 2$, dan X3 sebesar 69,0\% sedangkan sisanya sebesar 0,310 atau $31,0 \%$ merupakan pengaruh dari factor lain yang tidak diteliti dalam penelitian ini.

Persamaan 2:

1. Koefisien jalur X1 adalah 0,405 dengan arah positif, maka terdapat hubungan yang searah antara X1 dengan Z. Artinya jika X1 meningkat satu satuan maka $Z$ akan meningkat sebesar 0,405 begitu juga sebaliknya.

2. Koefisien jalur X2 adalah 0,277 dengan arah positif, maka terdapat hubungan yang searah antara X2 dengan Z. Artinya jika X2 meningkat satu satuan maka $\mathrm{Z}$ akan meningkat sebesar 0,277 begitu juga sebaliknya. 
3. Koefisien jalur X3 adalah 0,154 dengan arah positif, maka terdapat hubungan yang searah antara X3 dengan Z. Artinya jika X3 meningkat satu satuan maka $\mathrm{Z}$ akan meningkat sebesar 0,154 begitu juga sebaliknya.

4. Nilai $R$ square adalah 0,690 , artinya variable $\mathrm{Z}$ dipengaruhi oleh $\mathrm{X} 1, \mathrm{X} 2$, $\mathrm{X} 3$, dan $\mathrm{Z}$ sebesar $95,9 \%$ sedangkan sisanya sebesar 0,041 atau $4,1 \%$ merupakan pengaruh dari factor lain yang tidak diteliti dalam penelitian ini.

Berdasarkan model di atas dapat diketahui hubungan antar variabel independen terhadap variabel dependen dijelaskan pada berikut ini:

Ringkasan Uji Hipotesis pengaruh langsung

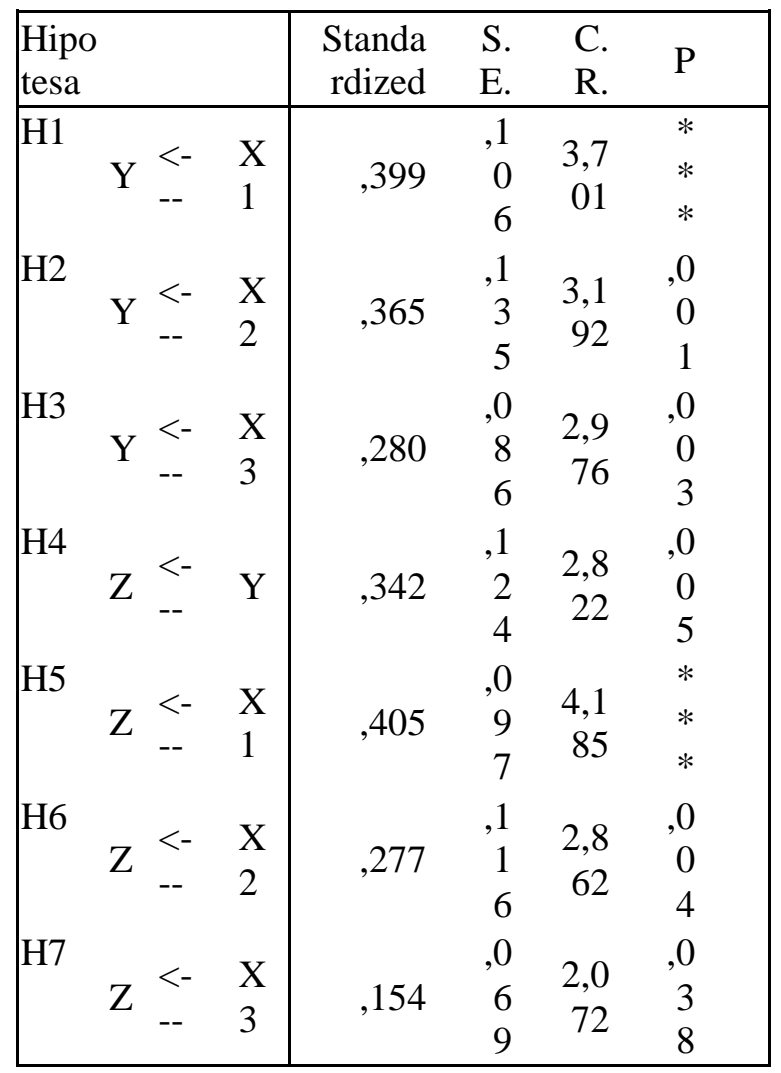

Sumber : data diolah

Hipotesa umum yang digunakan adalah sebagai berikut:
Ho Variabel independen tidak berpengaruh signifikan terhadap variabel dependen

Ha Variabel independen berpengaruh signifikan terhadap variabel dependen

Dasar pengambilan keputusan untuk pengujian ini adalah sebagai berikut :

Jika $\mathrm{P}<0,05$ atau CR $>1,96$ pada level $\alpha 5 \%$, maka $\mathrm{H}_{0}$ ditolak

Jika $\mathrm{P}>0,05$ atau $\mathrm{CR}<1,96$ pada level $\alpha 5 \%$, maka $\mathrm{H}_{0}$ diterima

Untuk uji mediasi menggunakan sobel test, yang dilakukan menggunakan kalkulator online pada website http://quantpsy.org/sobel/sobel.htm.

Diperoleh hasil sebagai berikut:

Hasil uji mediasi Promosi (X1) terhadap Minat Penggunaan E-Wallet (Z) melalui Kepercayaan (Y)

\begin{tabular}{|c|c|c|c|c|}
\hline $500.12 t$ & $\mathrm{~b}^{626 \mathrm{f}} \mathrm{9 \|}$ & \multicolumn{3}{|c|}{ C $9|\mathrm{Cn}| \mathrm{s}: 6$} \\
\hline $5^{9} 0.100$ & eooqugu f6ef: & 225338177 & 0.05955347 & 0.05185001 \\
\hline $60.3+9$ & 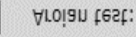 & 2.1895423 & 0.06278277 & 0.02855745 \\
\hline 90325 & टорө| fєеf: & 2.23уб58з5 & $0.06708+32$ & 0.02577371 \\
\hline Iubnf: & & 16аf аfэflef|c: & ટfq' EM.OL: & $b-\wedge 9 \mid \cap 6:$ \\
\hline
\end{tabular}

Sumber : data diolah

Hasil uji mediasi Persepsi Kemudahan (X2) terhadap Minat Penggunaan E-Wallet (Z) melalui Kepercayaan (Y)

\begin{tabular}{|c|c|c|c|c|}
\hline $5 b 0.724$ & $\mathrm{~b} \in 26 \mathrm{q} 9 \|$ & \multicolumn{3}{|c|}{ Cو|crisf } \\
\hline $2^{3} 0.135$ & eooqugu f6ef: & 2. & 0.0е20е0аs & 0.030 tesoe \\
\hline$P 0.3+9$ & 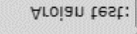 & 2.05080672 & 0.01300223 & 0.04028583 \\
\hline$=0.72 a$ & ટ૦рఠ| fGבf: & $2.06 a 42 \pi 5$ & $0.05 \sqrt{0} 08$ & 0.035 .12255 \\
\hline Iubnif: & & 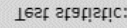 & 2fq' ELLOL: & D-^९|กє: \\
\hline
\end{tabular}

Sumber : data diolah

Hasil uji mediasi Persepsi Manfaat

(X3) terhadap Minat Penggunaan E-Wallet (Z) melalui Kepercayaan (Y)

\begin{tabular}{|c|c|c|c|c|}
\hline$a^{b} 0.127$ & $\mathrm{~b} \in 2 \in \mathrm{g} \mathrm{s} \|$ & & 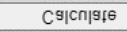 & \\
\hline$a^{9} 008 e$ & eooqugu fGaf: & $2.10528 \mathrm{I}+9$ & $0.0725752 \mathrm{e}$ & $0.03525 e 8 \mathrm{I}$ \\
\hline b0.379 & Ұlo!gu fGef: & Ј228581033 & 0.04788 .57 & 0.04738 .92 \\
\hline 20.255 & 20p & 2.04132834 & 0.0ง35деел & 0.0472782 \\
\hline Iubnif: & & 16ағ ағ9ғағас: & 2fq' ELLOL: & D-^९|กє: \\
\hline
\end{tabular}

Sumber : data diolah

\section{Pembahasan}




\section{Pengaruh Promosi Terhadap Kepercayaan}

Hasil pengujian hipotesis berdasarkan uji t seperti table dengan $\mathrm{t}$ hitung $(3,701)>t$ table $(1,96)$ dan koofisien jalur bernilai positif $(0,399)$ membuktikan bahwa promosi berpengaruh positif dan signifikan terhadap kepercayaan.

Hasil penelitian yang diperoleh terdapat pengaruh promosi terhadap Kepercayaan penggunaan E-Wallet Pada masyarakat di Kota Banjarmasin. Hal ini menjelaskan bahwa tingkat promosi yang dilakukan oleh penyedia E-Wallet akan mempengaruhi Kepercayaan Masyarakat Kota Banjarmasin untuk menggunakan E-Wallet dan ini sesuai dengan teori tentang tujuan promosi yang dikemukakan oleh Koetler (2012: 541), bahwa Promosi sebagai unsur utama dalam kampanye pemasaran, adalah berbagai kumpulan alat-alat insentif yang sebagian besar berjangka pendek, yang dirancang untuk merangsang pembelian produk atau jasa tertentu dengan lebih cepat dan lebih besar oleh konsumen.

Fenomena di lapangan, masyarakat sangat tertarik dengan $e$ wallet karena gencarnya promosi yang dilakukan oleh penyedia yang menawarkan berbagai hadiah, berupa cashback, diskon dan berbagai kemudahan transaksi sehingga mereka percaya bahwa penyedia E-Wallet akan memberikan hasil yang memuaskan kepada pelanggan dan merasa penyedia ewallet mempunyai reputasi yang bagus.

Promosi yang dilakukan akan menarik perhatian calon kosumen, yang kemudian perhatian tersebut akan beralih menjadi rasa ketertarikan. Ketertarikan dipengaruhi oleh trust (kepercayaan) terhadap suatu produk.

.Hasil penelitian ini mendukung penelitian yang dilakukan oleh Wijayanto (2018:370) bahwa promosi berpengaruh positif dan signifikan terhadap kepercayaan konsumen. Hasil ini juga mendukung penelitian yang dilakukan oleh Saputra, dkk (2020:7) yang menyatakan bahwa promosi berpengaruh positif dan signifikan terhadap kepercayaan konsumen.

\section{Pengaruh Persepsi Kemudahan Terhadap Kepercayaan}

Hasil pengujian hipotesis berdasarkan uji $\mathrm{t}$ seperti table dengan $\mathrm{t}$ hitung $(3,192)>t$ table $(1,96)$ dan koofisien jalur bernilai positif $(0,365)$ membuktikan bahwa persepsi kemudahan berpengaruh positif dan signifikan terhadap kepercayaan.

$\begin{array}{lcr}\text { Hasil } & & \begin{array}{r}\text { Penelitian } \\ \text { menunjukkan }\end{array} \\ \text { kemudahan } & \text { becara } & \text { persepsi } \\ \text { memiliki } & \text { pengaruh } & \text { terhadap } \\ \text { kepercayaan. } & \text { Semakin } & \text { tinggi }\end{array}$
Persepsi Kemudahan yang dirasakan konsumen, maka akan semakin tinggi juga tingkat Kepercayaan konsumen terhadap E-Wallet. Dengan banyaknya kemudahan yang diberikan penyedia E-Wallet menjadikan konsumen merasa percaya jika melakukan transaksi mengunakan E-Wallet. Hal ini sesuai dengan teori TAM, bahwa Attitude towards behavior (sikap terhadap perilaku) didefinisikan oleh Davis sebagai perasaan-perasaan positif atau negatif dari seseorang jika harus melakukan perilaku yang akan ditentukan. Jika seseorang merasa percaya bahwa sistem informasi mudah digunakan maka dia akan menggunakannya (2020:16).

Fenomena di lapangan, masyarakat tidak mengalami kesulitan dalam mengakses $e$-wallet $d a n$ belajar menggunakan $e$-wallet dengan cepat. Hal ini meningkatkan kepercayaan kepada penyedia $e$ wallet dan yakin akan reputasinya 
serta akan memberikan hasil yang memuaskan pelanggannya.

Hasil temuan ini memperkuat penelitian yang dilakukan oleh Wahyuningsih (2019:96) yang meneliti hipotesis tersebut yang menyatakan bahwa persepsi kemudahan berpengaruh positif dan signifikan terhadap kepercayaan. Hal ini juga mendukung penelitian dari Faradilla,dkk (2016:149) bahwa persepsi kemudahan berpengaruh positif dan signifikan terhadap kepercayaan konsumen. Hal ini menunjukkan bahwa persepsi tentang adanya kemudahaan yang di rasakan oleh konsumen akan semakin meningkatkan kepercayaan konsumen terhadap suatu produk.

\section{Pengaruh Persepsi Manfaat Terhadap Kepercayaan}

Hasil pengujian hipotesis berdasarkan uji t seperti table dengan $\mathrm{t}$ hitung $(2,972)>\mathrm{t}$ table $(1,96)$ dan koofisien jalur bernilai positif $(0,280)$ membuktikan bahwa persepsi manfaat berpengaruh positif dan signifikan terhadap kepercayaan. Hasil Penelitian diperoleh, menunjukkan bahwa persepsi manfaat secara langsung memiliki pengaruh terhadap kepercayaan. Semakin tinggi Persepsi Manfaat yang dirasakan konsumen, maka akan semakin tinggi juga tingkat Kepercayaan konsumen terhadap E-Wallet. Dengan besarnya manfaat yang diberikan oleh penyedia E-Wallet dapat menimbulkan perasaan yang positif bagi konsumen, terutama tentang kepercayaan, karena pada dasarnya konsumen akan cenderung menyukai aplikasi yang bermanfaat. Hal ini sesuai dengan teori TAM, bahwa Attitude towards behavior (sikap terhadap perilaku) didefinisikan oleh Davis sebagai perasaan-perasaan positif atau negatif dari seseorang jika harus melakukan perilaku yang akan ditentukan. Jika seseorang merasa percaya bahwa sistem informasi mudah digunakan maka dia akan menggunakannya (2020:16).

Hasil Penelitian ini memperkuat penelitian yang dilakukan oleh Nurzanita,dkk (2020:277) yang menyatakan bahwa persepsi manfaat berpengaruh positif dan signifikan terhadap kepercayaan. Hal ini juga mendukung penelitian dari Widya,dkk (2020:374) bahwa persepsi manfaat berpengaruh positif dan signifikan terhadap kepercayaan konsumen. Hal ini menunjukkan bahwa persepsi tentang adanya manfaat yang di rasakan oleh konsumen, akan semakin meningkatkan kepercayaan konsumen terhadap suatu produk.

\section{Pengaruh Kepercayaan Terhadap Minat Pengunaan}

Hasil pengujian hipotesis berdasarkan uji t seperti table dengan $\mathrm{t}$ hitung $(2,822)>\mathrm{t}$ table $(1,96)$ dan koofisien jalur bernilai positif $(0,342)$ membuktikan bahwa kepercayaan berpengaruh positif dan signifikan terhadap minat penggunaan.

Hasil dari penelitian yang menguji pengaruh kepercayaan secara langsung terhadap minat penggunaan E-Wallet terdapat pengaruh yang positif dan signifikan. Hal ini sesuai dengan teori (Darwin dan Konto, 2014:3) bahwa kepercayaan itu terkait tentang keyakinan bahwa suatu pihak akan dilindungi dan tidak akan dirugikan oleh pihak yang dipercayai dan 
akhirnya akan menyebabkan kepercayaan kepada penyedia semakin tinggi. Dengan Semakin tinggi kepercayaan seseorang terhadap penyedia E-Wallet maka semakin besar minat penggunaannya. Keputusan konsumen juga dipengaruhi oleh nilai-oleh nilai-nilai inti, sistem kepercayaan yang mendasari sikap dan perilaku. Nilai-nilai inti jauh lebih dalam dari perilaku atau sikap dan cara menentukan, pada tingkat dasar, pilihan konsumen dan keinginan dalam jangka panjang.

Fenomena di lapangan, pengguna e-wallet yakin dengan reputasi penyedia serta percaya bahwa penyedia akan memberikan hasil yang memuaskan kepada pelanggannya. Hal ini meningkatkan minat mereka untuk menggunakan ewallet dan dengan senag hati menggunakannya bahkan merekomendasikan kepada keluarga dan rekan-rekan mereka.

Penelitian ini juga menguatkan penelitian sebelumnya oleh Ambarwati (2019:88), bahwa kepercayaan berpengaruh positif dan siginifikan terhadap minat penggunaan. Hal ini juga sejalan dengan penelitian Wibowo (2018:16), bahwa kepercayaan berpengaruh siginifikan terhadap minat penggunaan. Hal ini menunjukkan bahwa semakin tinggi tingkat kepercayaan, maka konsumen akan merasa nyaman dan tertarik menggunakan E-Wallet.

\section{Pengaruh Promosi Terhadap Minat Penggunaan}

Hasil pengujian hipotesis berdasarkan uji t seperti table dengan $\mathrm{t}$ hitung $(4,185)>\mathrm{t}$ table $(1,96)$ dan koofisien jalur bernilai positif $(0,405)$ membuktikan bahwa kepercayaan berpengaruh positif dan signifikan terhadap minat penggunaan.

Berdasarkan hasil penelitian tentang pengaruh promosi terhadap minat penggunaan EWallet menunjukkan bahwa terdapat pengaruh positif dan sinifikan promosi terhadap minat pengunaan. Hal ini sesuai dengan Kotler dan Amstrong (2016:47) bahwa bauran pemasaran, yang salah satunya promotion mempunyai peranan yang sangat penting dalam mempengaruhi pelanggan untuk membeli produk atau jasa yang ditawarkan pasar.

Fenomena di lapangan, kegiatan promosi yang dilakukan oleh penyedia $e$-wallet di situs web mampu menarik minat konsumen untuk membeli dan mampu membangkitkan keinginan untuk mengetahui lebih dalam mengenai produk e-wallet. Kemudian ditambah lagi dengan promo berupa hadiah oleh $e$-wallet mampu menarik minat konsumen untuk membeli. Sehingga mereka merasa senang menggunakan layanan $e$-wallet dan berkeinginan untuk terus menggunakan layanan E-Wallet dibanding dengan layanan lainnya. Hasil penelitian ini juga mendukung penelitian sebelumnya oleh Dirwan dan Latief (2020:7), bahwa promosi berpengaruh positif dan signifikan terhadap minta penggunaan E-Wallet. Begitu juga menguatkan penelitian sebelumnya bahwa promosi juga berpengaruh positif dan signifikan terhadap minat penggunaan (Fikri,dkk 2020:76).

\section{Pengaruh Persepsi Kemudahan Terhadap Minat Pengunaan}

Hasil pengujian hipotesis berdasarkan uji $\mathrm{t}$ seperti table dengan $\mathrm{t}$ hitung $(2,862)>\mathrm{t}$ table $(1,96)$ dan 
koofisien jalur bernilai positif $(0,277)$ membuktikan bahwa persepsi kemudahan berpengaruh positif dan signifikan terhadap minat penggunaan.

Hasil penelitian yang diperoleh dalam pengaruh persepsi kemudahan terhadap Minat Penggunaan E-Wallet Pada masyarakat di Kota Banjarmasin menunjukkan terdapat pengaruh positif dan signifikan. Hasil penelitian ini sesuai dengan teori Technology Acceptance Model (TAM) yang menjelaskan bahwa menggunakan sistem tertentu akan bebas dari usaha. Kemudahan menggunakan mampu mengurangi usaha seseorang baik waktu maupun tenaga untuk mempelajari sistem atau teknologi karena individu yakin bahwa sistem atau teknologi tersebut mudah untuk dipahami. Intensitas penggunaan dan interaksi antara pengguna (user) dengan sistem juga dapat menunjukkan kemudahan penggunaan. Sistem yang lebih sering digunakan menunjukkan bahwa sistem tersebut lebih dikenal, lebih mudah dioperasikan dan lebih mudah digunakan oleh penggunanya.

Fenomena di lapangan, pengguna $e$-wallet merasakan berbagai kemudahan diantaranya kemudahan dalam mempelajari yang bisa dilakukan dengan cepat, kemudian kemudahan di dalam pengoperasian yang bisa dilakukan secara fleksibel dimana saja. Begitu juga kemudahan dalam mendapatkan informasi tentang e-wallet. Hal ini semakin meningkatkan minat mereka untuk menggunakan $e$-wallet karena adanya berbagai kemudahan dan bahkan merekomendasikan kepada rekan-rekan dan keluarganya.

Hasil penelitian ini sesuai dengan penelitian yang dilakukan oleh Zulqurnain (2017:92), bahwa persepsi kemudahan mempengaruhi minat menggunakan e-money secara positif dan signifikan. Kemudian juga mendukung penelitian sebelumnya oleh Saras Sati, dkk (2020:16) bahwa persepsi kemudahan berpengaruh positih terhadap minat penggunaan.

\section{Pengaruh Persepsi Manfaat Terhadap Minat Penggunaan}

Hasil pengujian hipotesis berdasarkan uji t seperti table dengan $\mathrm{t}$ hitung $(2,072)>\mathrm{t}$ table $(1,96)$ dan koofisien jalur bernilai positif $(0,154)$ membuktikan bahwa persepsi manfaat berpengaruh positif dan signifikan terhadap minat penggunaan.

Hasil penelitian yang diperoleh dalam pengaruh persepsi manfaat terhadap Minat Penggunaan E-Wallet Pada masyarakat di Kota Banjarmasin menunjukkan terdapat pengaruh positif dan signifikan. Hasil penelitian ini sesuai dengan teori Technology Acceptance Model (TAM) yang menjelaskan bahwa menggunakan sistem dianggap mampu untuk meningkatkan kinerja dalam pekerjaan. Persepsi manfaat merupakan sejauh mana orang percaya bahwa menggunakan suatu teknologi akan meningkatkan kinerja dari pekerjaan. Minat beli merupakan perilaku konsumen yang menunjukkan sejauh mana komitmennya untuk melakukan pembelian. Kebutuhan dan keinginan konsumen akan barang dan jasa berkembang dari masa ke masa dan mempengaruhi perilaku mereka dalam pembelian produk.

Fenomena di lapangan, penggunaan layanan $e$-wallet dapat memperlancar segala macam transaksi. memberikan manfaat lebih seperti pembayaran tagihan, sehingga mempengaruhi minat untuk 
menggunakan E-Wallet. Begitu juga manfaat layanan $e$-wallet yang dapat menghemat biaya dalam melakukan transaksi. Hal ini semakin meningkatkan minat mereka untuk menggunakan $e$-wallet karena adanya berbagai kemudahan dan bahkan merekomendasikan kepada rekanrekan dan keluarganya.

Hasil penelitian ini sesuai dengan penelitian yang dilakukan oleh Anggit Anggoro (2019;1), bahwa persepsi manfaat mempengaruhi minat menggunakan e-money secara positif dan signifikan. Kemudian juga mendukung penelitian sebelumnya oleh Fikri,dkk (2020:76) bahwa persepsi kemudahan berpengaruh positih terhadap minat penggunaan.

\section{Pengaruh Persepsi Promosi Terhadap Minat Penggunaan Melalui Kepercayaan}

Hasil perhitungan diperoleh nilai $\mathrm{t}$ hitung nya 2,239 dengan $p$-value 0,025 . Nilai $t$ dengan tingkat signifikansi 0,05 adalah $\pm 1,96$ sehingga $t$ hitung $(2,239)>t \quad(1,96)$, membuktikan bahwa promosi berpengaruh positif dan signifikan terhadap minat penggunaan melalui kepercayaan.

Hasil analisis data menunjukkan bahwa pengaruh variabel Promosi berpengaruh signifikan terhadap minat penggunaan e-wallet melalui Kepercayaan. Secara langsung promosi berpengaruh signifikan terhadap penggunaan ewallet. Secara tidak langsung (dengan variabel kepercayaan sebagai variabel mediasi) promosi juga berpengaruh terhadap minat penggunaan e-wallet. Artinya kepercayaan mampu memediasi pengaruh promosi terhadap minat penggunaan e-wallet.

Hal ini mendukung penelitian yang dilakukan oleh
Hendro,dkk (2020:93) dan Khairiyah (2020:123), bahwa kepercayaan mampu memediasi pengaruh antara promosi dengan minat penggunaan.

\section{Pengaruh Persepsi Persepsi Kemudahan Terhadap Minat Penggunaan Melalui Kepercayaan.}

Hasil perhitungan diperoleh nilai $\mathrm{t}$ hitung nya 2,107 dengan p-value 0,035 . Nilai $t$ dengan tingkat signifikansi 0,05 adalah $\pm 1,96$ sehingga $t$ hitung $(2,107)>t \quad(1,96)$, membuktikan bahwa persepsi kemudahan berpengaruh positif dan signifikan terhadap minat penggunaan melalui kepercayaan.

Hasil analisis data menunjukkan bahwa pengaruh variabel persepsi kemudahan berpengaruh signifikan terhadap minat penggunaan e-wallet melalui Kepercayaan. Secara langsung persepsi kemudahan berpengaruh signifikan terhadap penggunaan ewallet. Secara tidak langsung (dengan variabel kepercayaan sebagai variabel mediasi) persepsi kemudahan juga berpengaruh terhadap minat penggunaan e-wallet. Artinya kepercayaan mampu memediasi pengaruh persepsi kemudahan terhadap minat penggunaan e-wallet.

Hasil ini berarti bahwa kepercayaan mampu memediasi secara positif dan signifikan pengaruh persepsi kemudahan penggunaan terhadap minat pengunaan e-wallet. Hal ini menunjukkan bahwa melalui adanya kepercayaan yang tinggi oleh pengguna terhadap kemudahan penggunaan e-wallet yang dirasakan juga akan menimbulkan minat penggunaan yang lebih tinggi.

Hal ini mendukung penelitian yang dilakukan oleh Sawitri,dkk (2020:379) dan Khairiyah (2019:72), bahwa kepercayaan 
mampu memediasi pengaruh antara persepsi kemudahan dengan minat penggunaan.

\section{Pengaruh Persepsi Manfaat Terhadap Minat Penggunaan Melalui Kepercayaan}

Hasil perhitungan

diperoleh nilai $\mathrm{t}$ hitung nya 2,041 dengan p-value 0,041 . Nilai $t$ dengan tingkat signifikansi 0,05 adalah $\pm 1,96$ sehingga $t$ hitung $(2,041)>t \quad(1,96)$.

Hasil analisis data menunjukkan bahwa pengaruh variabel persepsi manfaat berpengaruh signifikan terhadap minat penggunaan e-wallet melalui Kepercayaan. Secara langsung persepsi kemudahan berpengaruh signifikan terhadap penggunaan ewallet. Secara tidak langsung (dengan variabel kepercayaan sebagai variabel mediasi) persepsi manfaat juga berpengaruh terhadap minat penggunaan e-wallet. Artinya kepercayaan mampu memediasi pengaruh persepsi manfaat terhadap minat penggunaan e-wallet.

Hasil ini berarti bahwa kepercayaan mampu memediasi secara positif dan signifikan pengaruh persepsi manfaat penggunaan terhadap minat pengunaan e-wallet. Hal ini menunjukkan bahwa melalui adanya kepercayaan yang tinggi oleh pengguna terhadap manfaat penggunaan e-wallet yang dirasakan juga akan menimbulkan minat penggunaan yang lebih tinggi.

Hal ini mendukung penelitian yang dilakukan oleh Nurzanita,dkk (2020:284) dan Sawitri,dkk (2020:379), bahwa kepercayaan mampu memediasi pengaruh antara persepsi kemudahan dengan minat penggunaan.

\section{Kesimpulan}

Dengan berdasarkan dari hasil temuan dan pengujian hipoetsis yang telah dijelaskan sebelumnya, berikut beberapa kesimpulan yang dapat diambil dari hasil penelitian ini:

1. Promosi berpengaruh positif dan signifikan Terhadap Kepercayaan Pengguna E-Wallet di Kota Banjarmasin.

2. Persepsi Kemudahan berpengaruh positif dan signifikan Terhadap Kepercayaan Pengguna E-Wallet di Kota Banjarmasin.

3. Persepsi Manfaat berpengaruh positif dan signifikan Terhadap Kepercayaan Pengguna E-Wallet di Kota Banjarmasin.

4. Persepsi Kemudahan berpengaruh positif dan signifikan Terhadap Kepercayaan Pengguna E-Wallet di Kota Banjarmasin.

5. Promosi berpengaruh positif dan signifikan Terhadap Minat Penggunaaan E-Wallet di Kota Banjarmasin.

6. Persepsi Kemudahan berpengaruh positif dan signifikan Terhadap Minat Penggunaaan E-Wallet di Kota Banjarmasin.

7. Persepsi Manfaat berpengaruh positif dan signifikan Terhadap Minat Penggunaaan E-Wallet di Kota Banjarmasin.

8. Promosi berpengaruh positif dan signifikan terhadap minat penggunaan melalui kepercayaan Pengguna E-Wallet di Kota Banjarmasin.

9. Persepsi Kemudahan berpengaruh positif dan signifikan terhadap minat penggunaan melalui kepercayaan Pengguna E-Wallet di Kota Banjarmasin.

10. Persepsi Kemudahan berpengaruh positif dan signifikan terhadap minat penggunaan melalui kepercayaan Pengguna E-Wallet di Kota Banjarmasin.

\section{Daftar Pustaka}

Arikunto, S. 2010. Prosedur Penelitian Suatu Pendekatan Praktik. Jakarta: Rineka Cipta.

Armana, Made Adi,. Dkk. 2015. Pengaruh Biaya Promosi dan Tarif Kamar 
terhadap Pendapatan Hotel Damai di Singaraja Tahun 2013. E-Journal Bisma Universitas Pendidikan Ganesha Jurusan Manajemen (Volume 3 Tahun 2015)

Bangkara, Rajendra Prasada dan Ni Putu Sri Harta Mimba. 2016. Pengaruh perceived usefulness dan perceived ease of use pada minat penggunaan internet banking dengan attitude toward using sebagai variabel intervening.

Darwin, Steven \& Kunto, Yohanes Sondang. 2014. Analisis Kualitas Layanan Terhadap Loyalitas Pelanggan Dengan Kepuasan Dan Kepercayaan Pelanggan Sevagai Variabel Intervening Pada Asuransi Jiwa Manulife Indonesia-Surabaya. Jurnal Manajemen PemasaranPetra Vol. 2, No. 1. Hal:1-12

Dirwan., Latief, Fitriani. 2020. Aspek Yang Mempengaruhi Minat Penggunaan Uang Digital di Kota Makassar. Jurnal Mirai Management Volume 6 No.1.

Diyan Ambarwati, Dkk.2019. Pengaruh Persepsi Manfaat, Persepsi Kemudahan Dan Persepsi Kepercayaan Terhadap Keputusan Penggunaan Go-Pay Pada Mahasiswa Stie Aub Surakarta. Jurnal Bisnis dan Ekonomi Volume 6. P3M STIE AUB Surakarta.

Ghozali, I. Latan, H. (2012). Model Persamaan Struktural : Konsep, Teknik dan Aplikasi SEM AMOS. Semarang: Badan Penerbit Universitas Diponegoro.

Gitosudarmo, Indriyo. 2014. Manajemen Operasi. Yogyakarta: BPFE.

HongZhu, D., \& Ying L.Y.P. Chang, L. 2017. Understanding the Intention to Continue Use of a Mobile Payment Provider : An Examination of Alipay Walletin China. International Journal of Business and Information, 12(4).

Inayah, Romadhotul. 2020. Pengaruh Persepsi Kemudahan Penggunaan, Persepsi Kemanfaatan, dan Promosi Terhadap Minat Penggunaan uang elektronik Padamasyarakat (Studi Kasusdi Wilayah Kota Purwokerto). Purwokerto: Institut Agama Islam Negeri (IAIN).

Indriastuti, Maya., Rizki Herdian Wicaksono. 2014. Influencers E-Money in Banking Sector. South East Asia Journal of Contemporary Business, Economics and Law 4 (2).
Indriyo, Gitosudarmo. 2012. Manajemen Pemasaran. Yogyakarta: BPFEYogyakarta.

Kelah, Novrita Debora. 2020. Pengaruh Promosi, Persepsi Kemudahan, Dan Persepsi Manfaat Terhadap Minat Menggunakan E-Wallet (Studi Pada Mahasiswa Fakultas Ekonomi dan Bisnis Universitas Hasanuddin). FEB UNHAS

Kotler, Philip and Gary Armstrong. 2012. Prinsip-prinsip Pemasaran. Edisi 13. Jilid 1. Jakarta:Erlangga

Kusumastuti, Anggit Dyah. 2020. Pengaruh Pandemi Covid-19 terhadap Eksistensi Bisnis UMKMdalam mempertahankan Business Continuity Management(BCM).

eJournalAdministrasi Bisnis. Volume 8 , Nomor 3.

Muhibbin Syah. 2010. Psikologi Pendidikan dengan pendekatan baru.Bandung:PT. Remaja Rosdakarya.

Murwatiningsih., Apriliani, Erin Puri. 2013. Apakah Kepercayaan Konsumen Lebih Efektif Daripada F 103 n Harga?. Jurnal Dinamika M 103 1. Jurnal Dinamika Manajemє... т (4)

Nadhilla, Rahmi Syofyan (2021) Pengaruh Persepsi Manfaat, Kemudahan Penggunaan Dan Kepuasan Terhadap Minat Menggunakan Kembali E-Wallet Pada Masa Pandemi Covid-19 (Survei pada Pengguna E-Wallet OVO di Kota Padang). Diploma thesis, Universitas Andalas.

Nasri, W dan Charfeddine, L. 2012. Factors affecting the adoption of Internet banking in Tunisia : An integration theory of acceptance model and theoryof planned behavior. Journal of High Technology Management Research.

Nasri, Wadie dan Lanuoar Charfeddine. 2012. Factors Affecting the Adoption of Internet Banking in Tunisia: An Integration Theory of Acceptance Model and Theory of Planned Behavior. Journal of High Technology Management Research 23.

Nawawi, Juanda. 2012. Membangun Kepercayaan Dalam Mewujudkan Good Govermen. Jurnal Manajemen Publik Vol 1 No 1 Hal, 1-11

Ni Luh Putu Widya Sawitri, dkk. 2020. The Role of Trust Mediates the Effect of Perceived Ease of Use and Perceived Usefulness on Online Repurchase 
Intention. American Journal of Humanities and Social Sciences Research (AJHSSR) Volume-4.

Ni Putu Bella Novindra, Ni Ketut Rasmini. 2017. Pengaruh Kemudahan Penggunaan, Persepsi Kegunaan dan Computer self Efficacy pada Minat Penggunaan E-SPT. "E-jurnal Akuntansi Universitas Udayana, Vol.19.2. Mei (2017): 1116-1143.

Ujianto, dkk. 2019. Pedoman Penulisan Tesis Program Magister Manajemen STIE Pancasetia Banjarmasin. Penerbit Pancasetia.

Ponte, E. B., Carvajal-Trujillo, E., \& Escobar-Rodríguez, T. 2015. Influence Of Trust And Perceived Value On The Intention To Purchase Travel Online: Integrating The Effects Of Assurance On Trust Antecedents. Tourism Management, 47.

Purba, Samsir, Arifin. Riau, P. U. 2020. Pengaruh Persepsi Kemudahan Penggunaan, Persepsi Manfaat Dan Kepercayaan Terhadap Kepuasan dan NIAT Menggunakan Kembali Aplikasi Ovo Pada Mahasiswa Pascasarjana Universitas Riau. XII(1).

Reza Nurzanita, dkk.2020. Pengaruh persepsi manfaat terhadap keputusan penggunaan gopay di surabaya dengan kepercayaan sebagai variabel intervening. Jurnal AKUNTABEL 17. Samarinda.

Riduwan dan Engkos Achmad Kuncoro. 2011. Cara Menggunakan dan. Memaknai Analisis Jalur (Path Analysis). Cetakan Ketiga. Bandung: Alfabeta.

Rr. Selli Nisrina Faradila,dkk.2016 Analisis Pengaruh Persepsi Kemudahan Penggunaan dan Persepsi Manfaat terhadap Minat Beli dengan Kepercayaan Sebagai Variabel Intervening (Studi pada Pengunjung Toko Online berrybenka.com di Kalangan Mahasiswa Universitas Diponegoro). Jurnal Studi Manajemen \& Organisasi 13 (2016) Desember 149 - 160. Semarang

Setyo Ferry Wibowo, Dede Rosmauli, dan Usep Suhud. 2015. Pengaruh Persepsi Manfaat, Persepsi Kemudahan, Fitur Layanan, Dan Kepercayaan Terhadap Minat Menggunakan E-Money Card (Studi Pada Pengguna Jasa commuterline Di Jakarta)
Soegoto., dan S. S. R. Loindong. 2014. Pengaruh Kualitas. Produk, Harga, dan Lokasi terhadap Kepuasan Konsumen pada Warung-. Warung Makan Lamongan di Kota Manado. Jurnal EMBA. 2(3): 1766-. 1780.

Stanley Lemeshow, David W. Hosmer J, Janeile Klar \& Stephen K. Lwanga, 1997, Besar Sampel dalam Penelitian Kesehatan, Gajah Mada Uneversity Press, Yokyakarta, hal. 2

Sugiyono. 2010. Metode Penelitian Pendidikan Pendekatan Kuantitatif, kualitatif, dan R\&D. Bandung: Alfabeta.

Sugiyono. 2017. Metode Penelitian Kuantitatif, Kualitatif dan R\&D. Bandung: Alfabeta.

Sugiyono. 2017. Metode Penelitian Kuantitatif, Kualitatif, dan R\&D. Bandung: CV. Alfabeta.

Sunyoto, D. 2012. Manajemen Sumber Daya Manusia. Yogyakarta : CAPS

Swastha, Basu. 2014 Manajemen Penjualan. Yogyakarta:BPFE

Thomas Wijayanto,dkk.2018 Analisis Pengaruh Promosi Terhadap Loyalitas Konsumen Dengan Kepercayaan Sebagai Variabel Mediasi. Jurnal Ekonomi dan Kewirausahaan Vol. 18 No. 3. Surakarta

WHO. 2020. Pesan dan Kegiatan Utama Pencegahan dan Pengendalian COVID-19 di Sekolah, UNICEF PACIFIC

Wibowo, Setyo Ferry, Dede Rosmauli, Usep Suhud. 2015. Pengaruh Persepsi Manfaat, Persepsi Kemudahan, Fitur Layanan, Dan Kepercayaan Terhadap Minat Menggunakan E-Money Card (Studi Pada Pengguna Jasa Commuterline Di Jakarta). Jurnal Riset Manajemen Sains Indonesia (Jrmsi), Vol. 6, No. 1.

Widiyanti, Wiwik. 2020. Pengaruh Kemanfaatan, Kemudahan Penggunaan dan Promosi terhadap Keputusan Penggunaan E-wallet OVO di Depok. Jurnal Akuntansi danKeuangan. Volume 7 No. 1.

Winarsunu, Tulus. 2002. Statistik dalam Penelitian Psikologi dan Pendidikan. Malang : UMM Press.

Zulqurnain, Sholehuddin. 2017. Pengaruh Daya Tarik Promosi, Persepsi Kemudahan, Dan Persepsi Kemanfaatan Terhadap Minat Menggunakan E-Money (Studi Pada 


\section{Mahasiswa Universitas Gadjah Mada). Yogyakarta: Universitas Islam Negeri Sunan Kalijaga.}

Media online :

https://www.bi.go.id/id/edukasi/Pages/Apa-

itu-Uang-Elektronik.aspx diakses pada tanggal 5 Mei 2021

https://www.republika.co.id/berita/qpc9e642 3/pengguna-dompet-digital-meningkatdrastis-di-masa-pandemi diakses pada tanggal 5 Mei 2021

https://www.liputan6.com/tekno/read/44720

06/ini-daftar-dompet-digital-yang-paling-

banyak-digunakan-orang-indonesia diakses pada tanggal 5 Mei 2021 